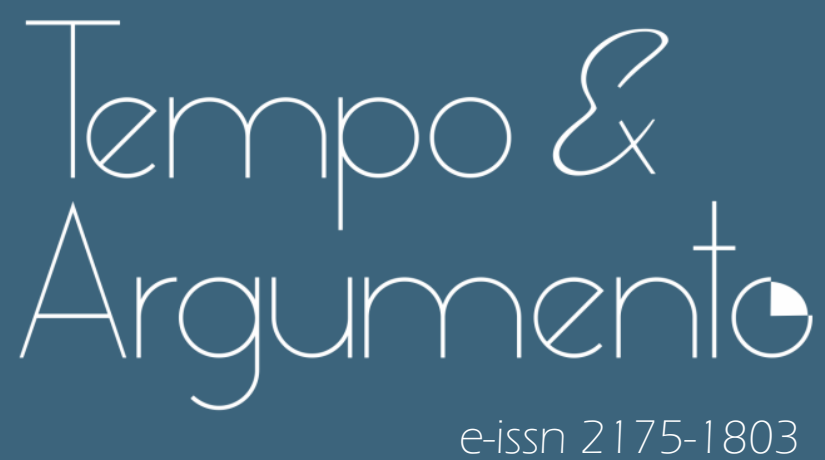

\title{
Tony Tornado, racismo e construções discursivas de um corpo negro em tempos de ditadura (1970-1972)
}

\section{- Amanda Palomo Alves}

Doutora em História pela Universidade Federal Fluminense (UFF).

Estágio Pós-Doutoral Universidade Estadual do Oeste do Paraná (UNIOESTE).

Pesquisadora no Grupos de Pesquisa: "Áfricas" no Instituto de História da

Universidade do Estado do Rio de Janeiro (UERJ) e "Africanias" da Escola de Música da Universidade Federal do Rio de Janeiro (UFR).

Rio de Janeiro, RJ - BRASIL

lattes.cnpq.br/2267421998231295

amanda.palomo@gmail.com

(D) orcid.org/0000-0003-4607-8041

\section{- Maria Cristina Giorgi}

Doutora em Estudos de Linguagem pela Universidade Federal Fluminense (UFF).

Professora do Centro Federal de Educação Tecnológica Celso Suckow da Fonseca (CEFET/RJ).

Rio de Janeiro, RJ - BRASIL

lattes.cnpq.br/3398338705307661

cristinagiorgi@gmail.com

(D) orcid.org/0000-0001-5347-6115

Para citar este artigo:

ALVES, Amanda Palomo; GIORGl, Maria Cristina. Tony Tornado, racismo e construções discursivas de um corpo negro em tempos de ditadura (1970-1972).

Tempo e Argumento, Florianópolis, v. 12, n. 31 , e0203, set./dez. 2020

doi http://dx.doi.org/10.5965/2175180312312020e0203

Recebido: 18/02/2020

Aprovado: 06/07/2020 


\title{
Tony Tornado, racismo e construções discursivas de um corpo negro em tempos de ditadura (1970-1972) ${ }^{1}$
}

\begin{abstract}
Resumo
O presente artigo reúne campos de investigação distintos, mas, complementares, ao aproximar história, relações étnico-raciais e estudos da linguagem. Nosso objetivo principal foi discutir o modo como os enunciados produzidos sobre o artista brasileiro, Tony Tornado, contribuem com a produção e reprodução de discursos racistas em nosso país. Para tanto, selecionamos notícias, artigos e reportagens publicados entre os anos 1970 e 1972 em revistas e jornais brasileiros. Nos debruçamos, também, na análise de pareceres da Censura, que evidenciam o "perigo" que Tony Tornado representava à certa estabilidade política e social do governo militar, pois, ao iluminar o problema da discriminação racial, o músico questionava o discurso de democracia racial, tão propalado no Brasil daqueles anos. Em nossa busca pelos efeitos de sentido, elegemos a análise do discurso enquanto referencial teórico e metodológico. Nessa direção, questionamos os enunciados produzidos sobre Tony Tornado e estivemos atentos às estratégias e marcas discursivas presentes nas revistas, nos jornais e nos pareceres da Censura. A análise do corpus nos permitiu identificar a construção de certa cadeia discursiva, e nos levou a compreender que a figura pública de Tony Tornado foi construída, também, com base no racismo.
\end{abstract}

Palavras-chave: Tony Tornado. Ditadura. Racismo. Mídia impressa. Discurso.

\section{Tony Tornado, racism and discursive constructions of a black body in dictatorship times (1970-1972)}

\begin{abstract}
This article interweaves the different, but complementary fields of history, ethnic-racial relations and language studies. Our main purpose was to discuss how the circulation of specific utterances regarding Brazilian artist Tony Tornado contributes to the production and reproduction of racist discourses in our country. For this purpose, we selected articles and news stories published in Brazilian magazines and newspapers between 1970 and 1972. We also dwelled on the analysis of censorship reports, which demonstrate how Tony Tornado, by shedding light on the issue of racial discrimination and questioning the thenwidespread discourse of racial democracy, constituted a "danger" to the political and social stability of the military government. We turned to discourse analysis as the theoretical and methodological framework guiding our investigation of meaning effects. As we examined utterances about Tony Tornado, we directed our attention to the strategies and the discursive cues found in the magazines, newspapers and censorship reports. The corpus analysis allowed us to identify the construction of a certain discursive chain, which, in turn, illuminated the ways in which the construction of Tony Tornado's public figure is based on racist practices and worldviews.
\end{abstract}

Keywords: Tony Tornado. Dictatorship. Racism. Print Media. Discourse. 
Tony Tornado, que de um dia para o outro, trocou o anonimato pelas primeiras páginas de todos os jornais do Brasil, anda tonto com o sucesso. Tony, que é um ótimo sujeito, anda morrendo de rir com os apelidos que leu nos jornais. Diz êle: -Agora, todo mundo me chama de O Ouriço do Festival, A Bomba do FIC, A Pérola Negra, A Dinamite Brasileira e outras milongas mais. Antigamente, eles me chamavam de Frango de Macumba (TV TUDO..., 1970, p. 13).

1. "Dos cabarés para a glória: Tony Tornado, furacão no festival” (DOS CABARÉS..., 1970, capa).

"Êsse crioulo vai longe" é o título de uma entrevista concedida por Tony Tornado² ao músico e, também jornalista, Silvio César. As declarações, publicadas originalmente na revista "Intervalo" (CÉSAR, 1970, p. 17), foram dadas momentos depois de divulgado o resultado final, da fase nacional, do V Festival Internacional da canção (V FIC) $)^{3}$. Naquela ocasião, a canção defendida por Tony Tornado, "BR3" (Antônio Adolfo/Tibério Gaspar), ficou classificada em primeiro lugar e defenderia o Brasil na fase internacional do festival. Vários periódicos dos anos 1970 noticiaram em suas capas a vitória de “BR-3”, entre eles, a Revista Intervalo: “Tony Tornado: furacão no festival” (TONY TORNADO: FURACÃO..., 1970, capa), Revista Manchete: "Tony Tornado: a viagem gloriosa para o sucesso" (TONY TORNADO: A VIAGEM..., 1970, capa), Revista Amiga: "Os heróis da BR-3" (OS HERÓIS DA BR-3..., 1970, capa) e Revista Aconteceu: "O povo elegeu BR-3 e Toni Tornado" (O POVO ELEGEU BR-3...., 1970, capa), como podemos verificar a seguir:

\footnotetext{
Antônio Viana Gomes, mais conhecido como Tony Tornado, nasceu no dia 26 de maio de 1931 na cidade de Mirante do Paranapanema, região oeste do Estado de São Paulo. Aos onze anos de idade, deixou a casa dos pais e se mudou para o Rio de Janeiro, onde trabalhou como vendedor de amendoim e engraxate. Na juventude, recebeu o nome artístico de "Toni Checker" ao participar do programa "Hoje é Dia de Rock" e dublar o cantor estadunidense Chubby Checker. Na segunda metade da década de 1960, Tornado viajou para a Europa junto com o grupo de dança "Brasiliana" e depois de terminada a turnê decidiu ir para os Estados Unidos, onde viveu, na clandestinidade, por alguns meses. As influências culturais e políticas que ele recebeu naquele período foram fundamentais para a sua trajetória artística, uma vez que teve um contato mais intenso com a soul music e com o movimento black power.

Em nosso país, os festivais da canção se transformaram num evento de grande amplitude justamente no período em que a indústria fonográfica e o mercado de discos iniciavam o seu processo de consolidação. Durante o V FIC, várias tendências musicais foram apresentadas, mas, podemos afirmar, que o soul foi amplamente destacado, um segmento novo no mercado, que se consolidava desde o final dos anos 1960 no Brasil. Nomes como os de Aretha Franklin, James Brown e Stevie Wonder, que vinham de gravadoras estadunidenses dedicadas ao soul, como a Motown, se popularizam em nosso país, influenciando compositores e músicos brasileiros. Naquele período, a black music já estava presente em bailes que aconteciam em pequenos salões nos bairros de diferentes localidades da cidade do Rio de Janeiro e, também, nos quintais das casas do subúrbio carioca (ALVES, 2010; 2019).
} 
Tony Tornado, racismo e construções discursivas de um corpo negro em tempos de ditadura (1970-1972)

Amanda Palomo Alves, Maria Cristina Giorgi

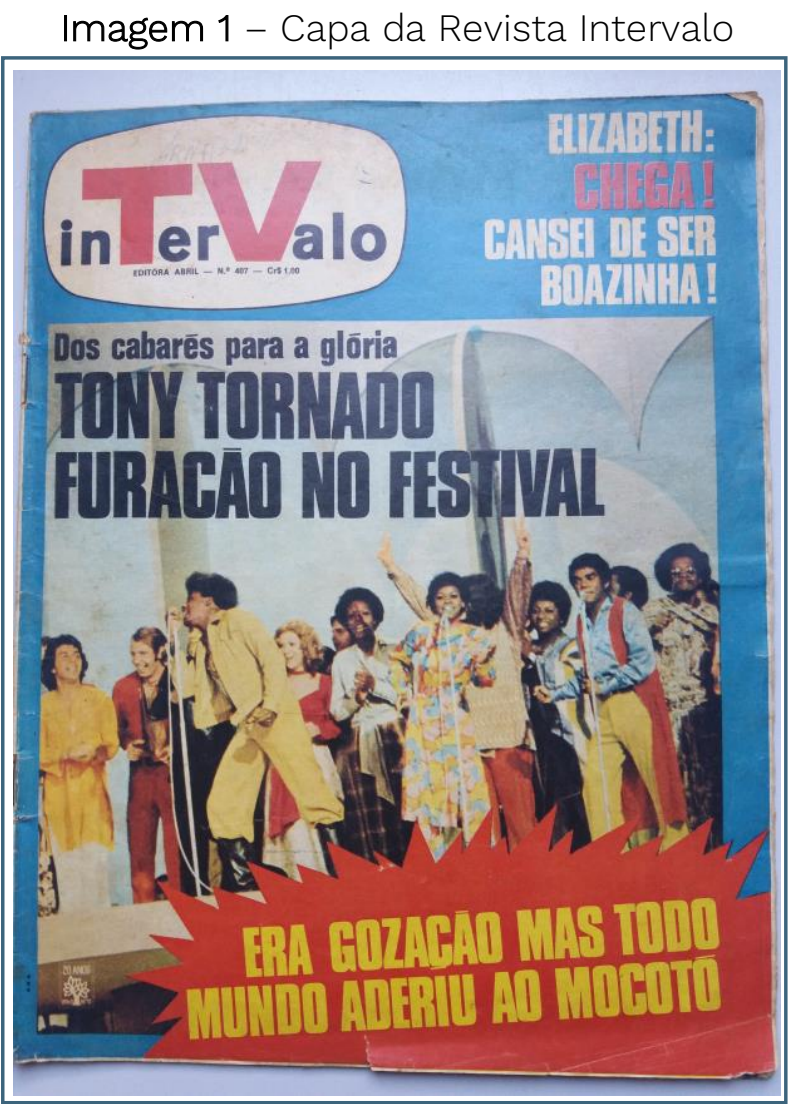

Fonte: TONY TORNADO: FURACÃO...,1970 [capa]

Imagem 2 - Capa da Revista Manchete

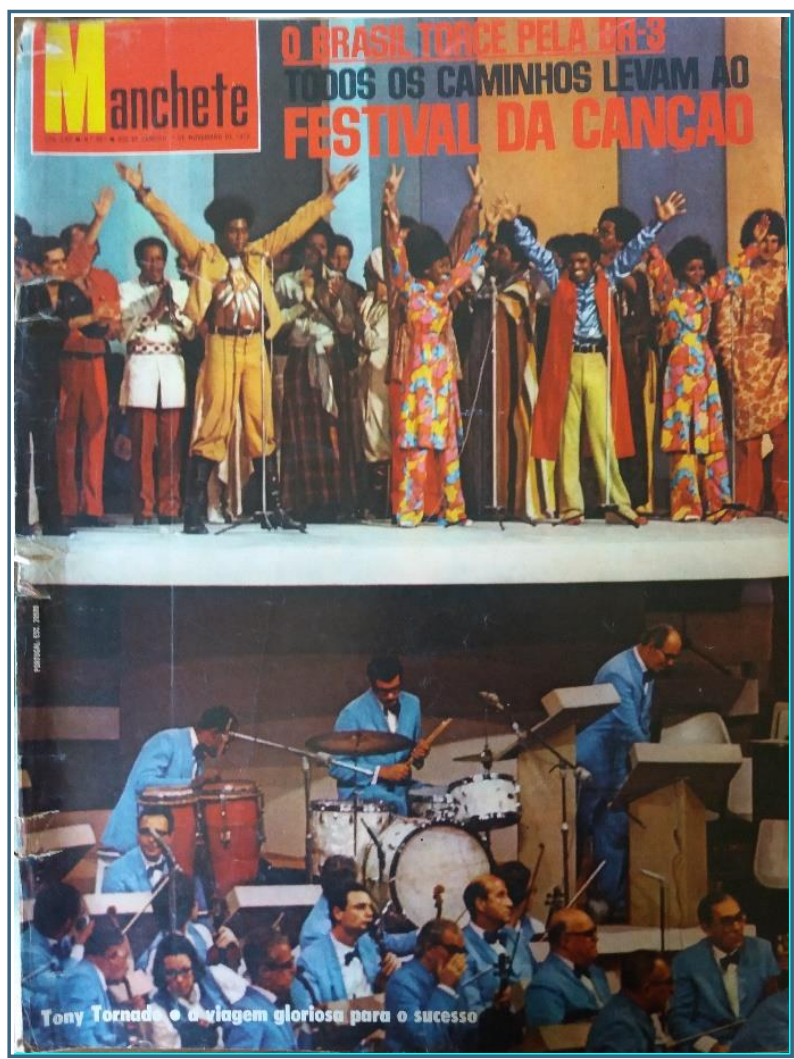

Fonte: O BRASIL..., 1970 [capa] 
Tony Tornado, racismo e construções discursivas de um corpo negro em tempos de ditadura (1970-1972)

Amanda Palomo Alves, Maria Cristina Giorgi

Imagem 3 - Capa da Revista Aconteceu

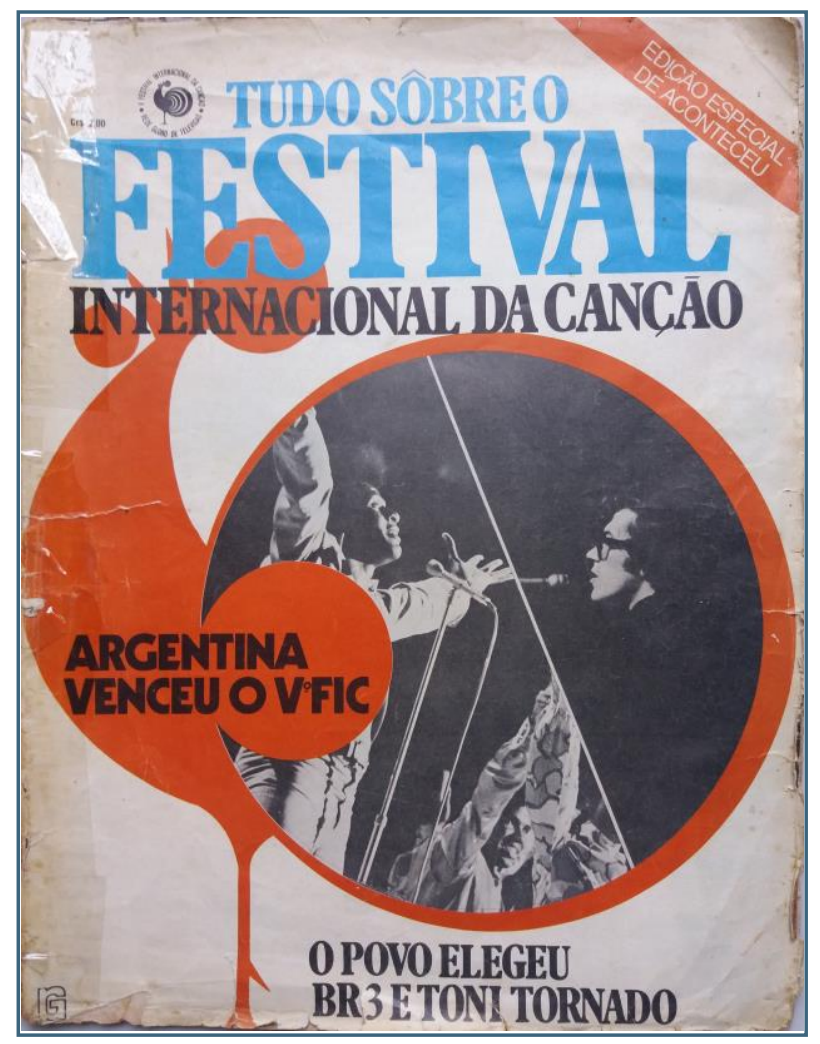

Fonte: O POVO..., 1970 [capa]

Imagem 4 - Capa da Revista Amiga

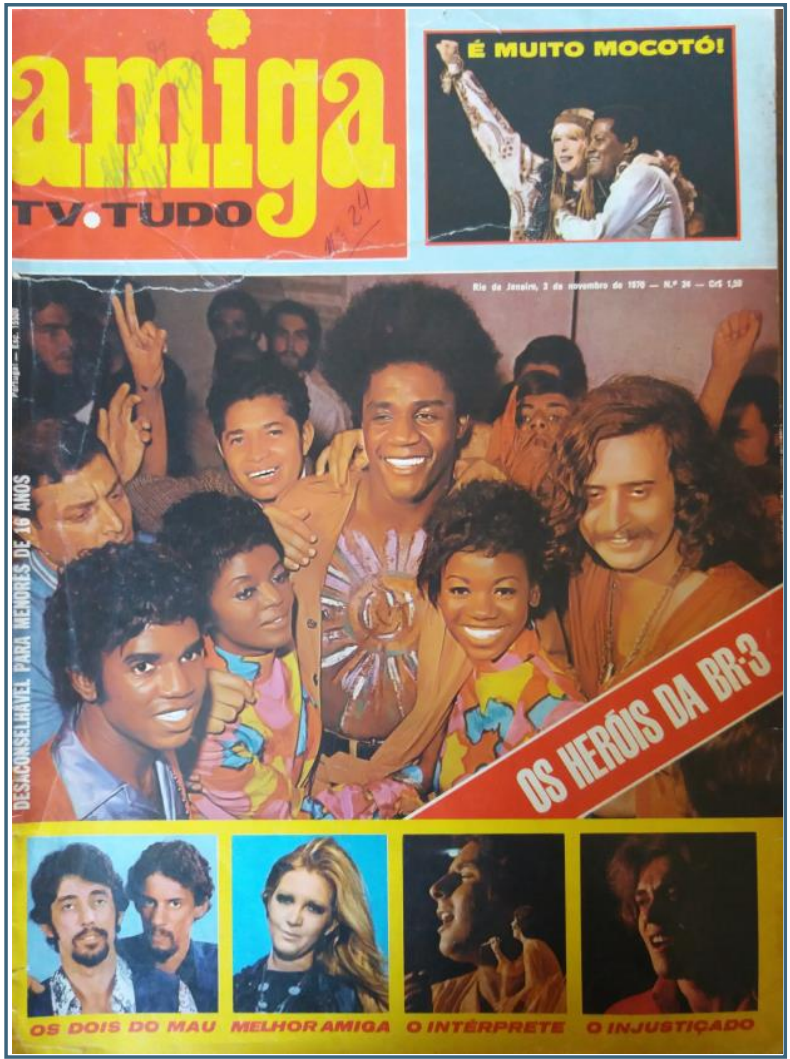

Fonte: OS HERÓIS..., 1970 [capa] 
Ao tratarmos capas de revistas como enunciados, questionamo-nos de que modo elas contribuem para a produção de sentidos. Para o filósofo da linguagem, Mikhail Bakhtin, a constituição do enunciado é de natureza dialógica e social. Em outras palavras, o enunciado não se restringe à sua dimensão linguística, pelo contrário, é necessário que estejamos sempre atentos à sua dimensão extraverbal (BAKHTIN, 1997; 2006). Julgamos importante sinalizar essas questões, pois sabemos que a recepção é um elemento importante para os que produzem e comercializam produtos midiáticos, como revistas. Ao observarmos as capas ilustradas anteriormente, verificamos que a articulação entre a dimensão linguística (frases que destacamos) e não linguística (imagens e cores utilizadas nas capas das revistas), contribuiu para a produção de efeitos sentidos. Assim, nas capas, o verbal e o visual fazem parte do mesmo processo de significação, primeiro, ao destacarem a figura de Tony Tornado e ao concebê-lo como um "novo herói nacional”, segundo, ao publicarem, junto à imagem do intérprete, os enunciados: "O povo elegeu BR-3 e Toni Tornado" (O POVO..., 1970, capa), "Os heróis da BR-3" (OS HERÓIS..., 1970, capa) e "Tony Tornado: a viagem gloriosa para o sucesso" (TONY TORNADO: A VIAGEM..., 1970, capa). Nessa direção, precisamos considerar, ainda, os sentidos atribuídos à figura de Tony Tornado que, naquele contexto, simbolizava um movimento musical novo, jovem e dançante, que se fortalecia em nosso país. A vitória de "BR-3" no festival angariou bons números de venda para o gênero soul no mercado fonográfico brasileiro, mas, também, transformou Tony Tornado numa celebridade nacional. A partir daquele momento, sua imagem e fatos de sua vida passaram a ser corriqueiramente veiculados em diferentes meios de comunicação da época.

Após anunciados os vitoriosos da fase nacional do V FIC, os compositores e o intérprete foram festejar na casa dos pais de Tibério Gaspar, conforme noticiou a revista "Intervalo": "FESTA DA VITÓRIA SÓ ACABOU NO DIA SEGUINTE". A pequena notícia, publicada na seção "Aqui as fofocas", informa: 
Champanha correndo à solta, quase botaram fogo na casa do pai de Tibério Gaspar, cheia de gente comemorando a vitória. Só quem não entrou muito na onda foi dona Isaura, mãe do Tibério que estava com alguma bronca de Tony Tornado, ninguém conseguia entender por quê. Foi quando pegaram dona Isaura pela mão e a levaram para um papo com o crioulo. Ela se surpreendeu com a tranquilidade e ar de gente boa do cantor. Só depois dona Isaura contou a causa da antipatia por Tony. Era coisa velha, de muitos anos. Os pais de Tibério haviam comprado uma fazenda e, na região, havia um crioulo enorme, 2 metros de altura, valentão, desordeiro, que ainda se reforçava com um revólver e mandava bala em qualquer um até sem motivo. Dona Isaura transferiu o medo do negrão baderneiro ao inocente cantor. (FESTA..., 1970, p. 06)

Em nossa busca pelos efeitos de sentido em discursos produzidos sobre Tony Tornado na imprensa periódica brasileira no início dos anos 1970, nos questionamos: quais enunciados sobre o sujeito negro - no caso, Tony Tornado - são produzidos? E ainda, quais estratégias e marcas discursivas estão presentes nos enunciados de notícias, artigos e reportagens? Num primeiro momento, notamos, na notícia em destaque, a presença no enunciado da palavra "crioulo" - marca discursiva que se repete em vários discursos produzidos sobre o artista no início dos anos 1970. Trata-se de uma designação utilizada especialmente no século XIX para indicar indivíduos de herança africana nascidos no Brasil, ou seja, nos remete ao período da escravidão. Os efeitos de sentido produzidos a partir dos enunciados "Só quem não entrou muito na onda foi dona Isaura, mãe do Tibério que estava com alguma bronca de Tony Tornado" e "Era coisa velha, de muitos anos" são endossados em seguida, com base na pequena narrativa descrita pelo enunciador-jornalista, que informa:

Os pais de Tibério haviam comprado uma fazenda e, na região, havia um crioulo enorme, 2 metros de altura, valentão, desordeiro, que ainda se reforçava com um revólver e mandava bala em qualquer um até sem motivo. Dona Isaura transferiu o medo do negrão baderneiro ao inocente cantor. (FESTA..., 1970, p. 06)

Ora, a comparação de Dona Isaura entre o "crioulo enorme, 2 metros de altura, valentão, desordeiro" (que morava próximo a sua fazenda) e Tony Tornado contribui para a construção de efeitos de sentido sobre o sujeito negro. Mas, afinal, quem é esse "Outro"? Que inspira desconfiança, medo e repulsa? E, ao mesmo tempo, é incapaz de inspirar "tranquilidade e ar de gente boa"? Como 
assinala Rosane Borges, as formas de "emoldurar o Outro" e de "fundi-lo em figuras restritas” (BORGES, 2012, p. 188) são práticas recorrentes na mídia. No caso da notícia em destaque, esse "Outro" - sujeito "valentão", "desordeiro" e perigoso, pois “mandava bala em qualquer um até sem motivo”, é comparado à figura de Tony Tornado. Sobre o tema, não poderíamos deixar de mencionar a obra de Celia Maria Marinho de Azevedo, “Onda negra, medo branco”, em que sua autora narra e contextualiza vários acontecimentos ocorridos no período da escravidão no Brasil e, também, no pós-abolição, e informa sobre o medo que fazendeiros, donos de terras e ex-senhores de escravos tinham da população escrava e recém-liberta. Esse medo era suscitado por várias notícias, entre elas, a sangrenta Revolução de São Domingos ${ }^{4}$, no Caribe, onde mulheres e homens escravizados se rebelaram contra a escravidão e colocaram em prática princípios da Revolução Francesa (AZEVEDO, 1987).

A aproximação de designações, como "crioulo", "valentão, "desordeiro", “medo", "negrão" e "baderneiro" nos permite identificar a construção de certa cadeia discursiva que produz efeitos de sentido que desqualificam a figura do intérprete de "BR-3", sujeito que, por suas características fenotípicas, torna-se incapaz de possuir um "ar de gente boa" ou ter "tranquilidade". Cabe ressaltarmos, ainda, que o termo “crioulo" - marcadamente estereotipado continuou sendo utilizado na sociedade brasileira por todo o século XX e, como sabemos, continua sendo.

Conforme já sinalizamos no início deste texto, a quinta edição do FIC propiciou resultados favoráveis para a indústria fonográfica no país e, Tony Tornado, com sua performance inspirada no cantor estadunidense James Brown, foi um dos responsáveis pela expansão do gênero soul que, no início dos anos 1970, não agradou, integralmente, compositores, críticos musicais e jornalistas

\footnotetext{
${ }^{4}$ No final do século XVIII, São Domingos era uma colônia francesa no Caribe. Na época, havia, aproximadamente, 500.000 habitantes na itha (em sua maioria, escravos). Em 1789, foi lançada a famosa Declaração dos Direitos do Homem e do Cidadão na França, um manifesto que declarava o descontentamento da burguesia francesa com os tradicionais e exorbitantes privilégios do Antigo Regime francês. Como explica Larissa Viana, os "ecos" de tais formulações da "ideologia revolucionária" chegaram às colônias francesas do Caribe, ainda naquele ano. Como informa a autora, até o ano de 1791 a escravidão não esteve no centro dos debates, em São Domingo, "quando uma grande revolta escrava fez a classe proprietária perceber que os ideais de liberdade foram compreendidos também pelo setor escravo". Aproximadamente cem mil escravos se envolveram na revolta (VIANA, 2014).
} 
brasileiros. Sobre o assunto, gostaríamos de destacar um artigo publicado na Revista Veja intitulado "MACACOS NOS SEUS GALHOS: perigos, erros e excessos das imitações" (MACACOS..., 1971, p. 79) que sugere, de modo bastante irônico, que o então ministro da fazenda, Delfim Netto, "taxasse ideias e práticas" que, segundo a revista, "não se adequavam à realidade da sociedade brasileira". Essas “ideias e práticas" seriam "produtos estrangeiros", como a "poluição do ar", a "liberdade feminina", "questões raciais" e a "soul music". Entretanto, como poderemos observar, o artigo em destaque apresenta uma forte carga racista ao inserir a imagem de Tony Tornado no canto superior direito da página e, ao centro, logo acima, a frase "MACACOS NOS SEUS GALHOS" (MACACOS..., 1971, p. 79):

Imagem 5 - "MACACOS NOS SEUS GALHOS"

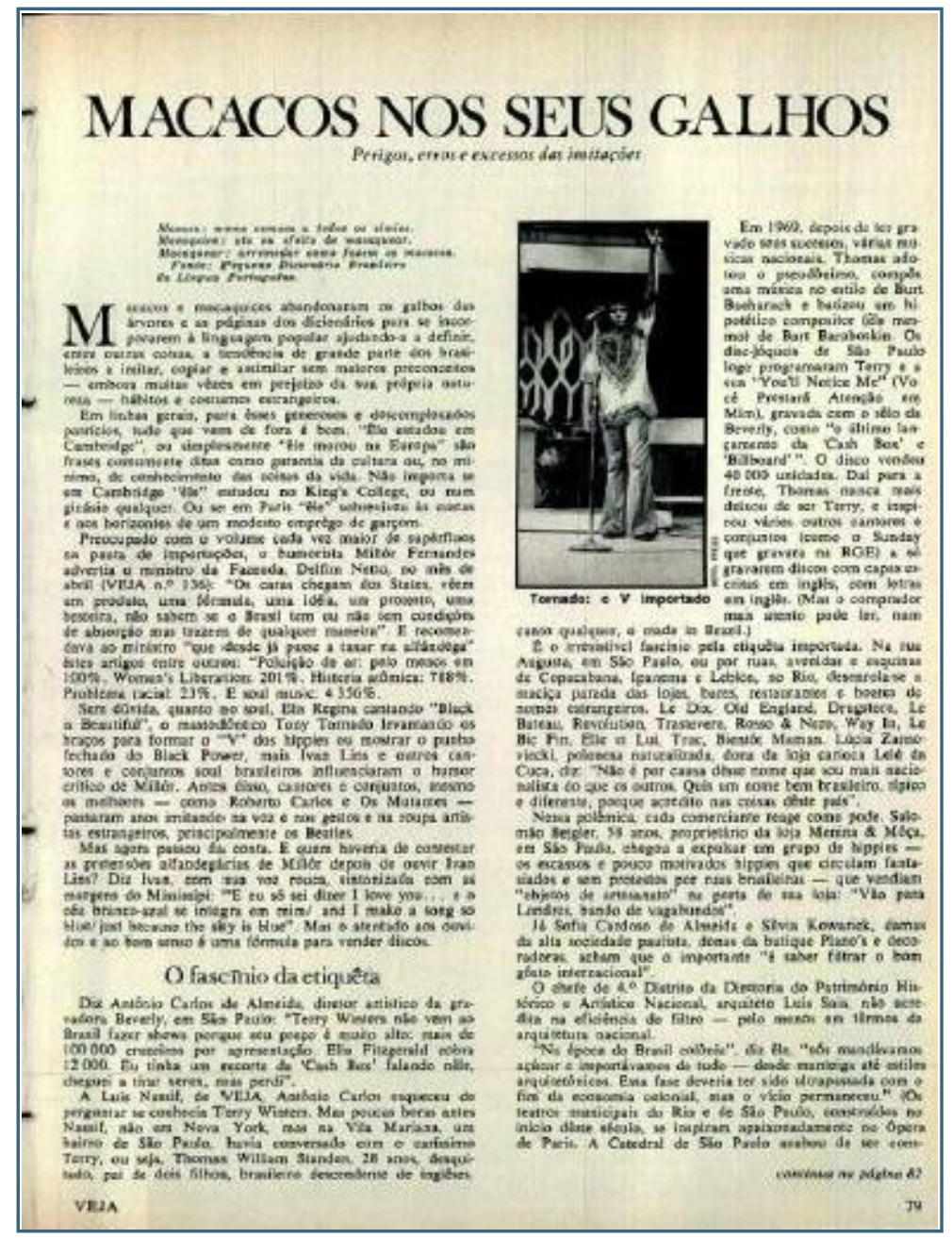

Fonte: MACACOS..., 1971, p. 79 


\begin{abstract}
"Os caras chegam dos States, vêem um produto, uma fórmula, uma ideia, um prosteso, uma besteira, não sabem se o Brasil tem ou não tem condições de absorção mas trazem de qualquer maneira". E recomenda ao ministro que "que desde já passe a taxar na alfândega" êstes artigos entre outros: "poluição de ar: pelo menos em 100\%; Women's Liberation: 201\%; Histeria atômica: 788\%, Problema racial: 23\%. E soul music: 4.356\%. Sem dúvida, quanto ao soul, Elis Regina cantando "Black is Beautiful", o mastodôntico Tony Tornado levantando os braços para formar o "V" dos hippies ou mostrar o punho fechado do Black Power, mais Ivan Lins e outros cantores e conjuntos soul brasileiros influenciaram o humor crítico de Millôr. Antes disso, cantores e conjuntos, mesmo os melhores - como Roberto Carlos e Os Mutantes - passaram anos imitando na voz e nos gestos e na roupa artística estrangeiros, principalmente, os Beatles. Mas agora passou da conta. (MACACOS..., 1971, p. 79)
\end{abstract}

Em uma das colunas publicadas na revista "O Cruzeiro", em 1970, o apresentador Flávio Cavalcanti entrevistou o compositor Nonato Buzar e perguntou a ele o que pensava sobre o desenvolvimento da soul music no Brasil: "Nós: Como vai a Soul Music no Brasil? Nonato: Soul no Brasil é uma piada. Na hora de se ganhar a preferência do povo é, "Luciana", "Sabiá", "Disparada" que são vencedoras. Os cantores que pega onda, berram e se esquecem que o negócio é alma" (UM INSTANTE..., 1970, p. 88). Na mesma época, o jornalista Sérgio Cabral também se posicionou, ao escrever uma reportagem para "O Pasquim", ironizando o V FIC e os músicos que se apresentaram naquela edição:

A apresentação de cada música deve merecer um cuidado especial para que nada indique que seja uma música brasileira. Se possível, não deve ter nenhum elemento de qualquer outro país que não sejam os Estados Unidos [...] na hora de cantar, o estilo deve ser soul. Como ninguém no Brasil sabe cantar neste estilo, a solução é fazer caretas como se da garganta saísse um som daqueles que emitem os cantores norte-americanos. (CABRAL, 1970, p. 10)

Realmente, a entrada de sons internacionais (principalmente dos Estados Unidos) no Brasil daqueles anos gerou várias polêmicas. Porém, com relação ao artigo "MACACOS NOS SEUS GALHOS", gostaríamos de destacar o enunciado "o mastodôntico Tony Tornado levantando os braços para formar o ' $V$ ' dos hippies ou mostrar o punho fechado do Black Power". Entendemos que a "referência animalesca" ao ato de imitação objetivava atingir, especialmente, a população negra de nosso país que passou incorporar (durante toda a década de 1970) 
“ideias estrangeiras". Além disso, salta aos nossos olhos a frase "MACACOS NOS SEUS GALHOS", escrita em negrito e em caixa alta. Novamente, o verbal "MACACOS NOS SEUS GALHOS" - e o visual (imagem de Tony Tornado, fazendo O "V" dos hippies), foram analisados como partes de um mesmo conjunto na produção de sentidos.

Vítimas das representações sociais e racistas, negros e negras de nosso país sempre carregaram (e ainda carregam), na própria aparência, a marca da inferioridade social. Por isso, enunciados como "mastodôntico", utilizado para caracterizar Tony Tornado, são insultos raciais e instrumentos de humilhação. Antonio Sérgio Guimarães esclarece que a função ou a intenção de um insulto podem variar, mas estão sempre ligadas a uma relação de poder. No caso específico dos insultos raciais,

[...] sua eficácia reside justamente em demarcar o afastamento do insultador em relação ao insultado, remetendo-o ao terreno da pobreza, da anomia social, da sujeira e da animalidade [...]. Quando se trata de insulto propriamente racial, a animalidade é atribuída principalmente através de termos como "macaco" e "urubu", usados indistintamente para ambos os sexos. (GUIMARÃES, 2000, sem paginação)

Em outras palavras, mais do que o termo, a própria cor adquire uma função simbólica que dialoga, também, com um imaginário europeu, surgido na Idade Média, construído pela ideia de monstros que, desde a Antiguidade, habitaram a África e a Ásia. Um mundo demoníaco e exótico que, conforme Gislene dos Santos (2002) era sempre pintado de preto. A construção dessa imagem "exótica" se sustenta na elaboração da ideia de inferioridade do negro, que passa a estar relacionada com a animalidade que se concretiza, no fragmento anterior, numa forma "mastodôntica”, reafirmando um imaginário presente desde a Idade Média. Consideramos importante destacar, ainda, que a reportagem relaciona o cantor aos hippies e ao black power. "O mastodôntico Tony Tornado levantando os braços para formar o "V" dos hippies ou mostrar o punho fechado do Black Power". Ora, naquele contexto, os dois movimentos não eram bem vistos por uma parcela considerável da população brasileira, além disso, quais seriam os efeitos de sentido dessa enunciação? Veremos adiante que outros periódicos da época relacionavam o cantor ao movimento black power e, ao fazerem tal 
associação, desqualificavam o músico, pois além dele suscitar questões sobre o racismo no Brasil, contestava o discurso de democracia racial, tão caro à ditadura ${ }^{5}$.

Não poderíamos deixar de comentar que passados alguns dias da final internacional do festival, o colunista social Ibrahim Sued publicou um artigo, sugerindo que "BR-3" seria um código dos viciados em drogas: uma veia do braço onde se injeta a cocaína. Tivemos acesso ao artigo intitulado "A barato-3", publicado pela revista "Veja" em 11 de novembro de 1970:

Dificilmente algum motorista terá encontrado nas curvas fechadas da velha estrada Rio-Belo Horizonte, a BR-3, o "sonho, viagem multicolorida, às vezes ponto de partida, às vezes porto de talvez", que a dupla de compositores Antônio Adolfo e Tibério Gaspar teve sensibilidade suficiente para descobrir. Graças a isso e com a ajuda da interpretação tonitruante de Tony Tornado, a BR-3 conquistou o Festival Nacional da Canção Popular e conseguiu o terceiro lugar da fase internacional. Agora, prosseguindo no longo filão rodoviário que abriram para a música popular brasileira, os dois jovens compositores anunciam uma nova canção, tendo como tema a estrada Transamazônica. Essa notícia, que talvez tenha provocado a satisfação de muitos engenheiros, despertou a curiosidade de alguns estranhos personagens habituados a belas viagens multicoloridas, por meio de suaves e perigosas picadas de injeções na veia mediana, exatamente no ponto em que ela se bifurca em duas outras veias: a mediana cefálica e a basílica mediana, na articulação do antebraço. Ao contrário das estradas convencionais, ela não é recoberta pela capa asfáltica, mas por uma túnica endotelial capaz de se enfraquecer com o excessivo trânsito de drogas diversas. Para eles, pouco habituados à linguagem da anatomia, a veia mediana é conhecida na gíria como a BR-3 de todos os "baratos" ou "viagens" (nomes dados ao estado provocado pelo efeito das drogas). Pelas suas dimensões, a Transamazônica deverá ser honrada, no mínimo com a carótida. (SUED, 1970, p. 24)

Não podemos deixar de marcar o tom irônico e pouco respeitoso do texto de Sued que se concretiza, por exemplo, na comparação da letra da música com veias que recebem o trânsito de drogas. Segundo Zuza Homem de Mello (2003),

\footnotetext{
Esse tema será retomado, mas, já podemos sinalizar, conforme Maria A. Aquino (1999), que durante a ditadura militar brasileira foram utilizados mecanismos para mascarar a alteridade social, procurando criar uma imagem de sociedade livre de conflitos. Para Antonio Sérgio Guimarães (1999) entre 1968 e 1978, a “democracia racial” passou a ser um dogma, uma espécie de ideologia de Estado. Nessa direção, os governos daquele período passaram a denunciar qualquer crítica à democracia racial como "atos de subversão", realizados por "esquerdistas que buscam criar novas fontes de tensão e insatisfação para com o regime e suas autoridades devidamente constituidas" (ANDREWS, 1997, p. 101-102)
} 
a finalidade do artigo era promover um livro chamado "Tóxico" escrito pelo amigo de Sued, o general Jaime Graça. Na capa vermelha, o título lembrava uma carreira de cocaína e nas primeiras páginas indicava que a música de Antônio Adolfo e Tibério Gaspar era um “hino ao toxicômano”, através da substituição dos versos: "Há uma seringa/ que vem do céu, cruzando o braço/ e uma agulha feita em aço/ pra espetar outra vez" (MELLO, 2003, p. 387-388). Depois de publicado o texto, Tibério Gaspar, letrista da canção, foi interrogado pelo chefe do Serviço Nacional de Informação $(\mathrm{SNI})^{6}$ e várias polêmicas em torno do intérprete surgiram.

\section{Tony Tornado: "o poder negro" no Brasil}

Ao observamos as imagens presentes nas capas de revistas (apresentadas no início deste artigo), pudemos visualizar que durante o festival, Tony Tornado exibia em seu peito a tatuagem de um sol. De acordo com o artista, o desenho fazia uma referência ao período em que viveu no bairro do Harlem, em Nova Iorque, e significava "ser de todos", ou seja, pertencer aos diferentes grupos presentes no bairro (TORNADO, 2009. Informação verbal) 7 . Na noite do festival, logo após a apresentação de "BR-3", vários jornalistas interpelaram os compositores da canção sobre o significado da tatuagem. A revista "Intervalo", em uma edição de outubro de 1970, lançaria a seguinte nota: "Segundo Tibério Gaspar, autor da música vencedora junto com Antônio Adolfo, tratou-se de uma homenagem ao deus-Sol, adorado no antigo Egito" (FIC..., 1970, p. 02). Nessa mesma direção, a revista "Amiga”, em matéria sobre o festival, não especifica o desenho e simplesmente comenta: "Vestido com uma roupa cáqui, bota longa, peito aberto e colorido, todo pintado sobre a pele escura, ele pisou no palco do Maracanãzinho com as mãos ao alto saudando o povo" (A GENTE..., 1970, p. 03). A explicação dada pelo letrista, mesmo sendo relatada pelo jornalista, nos fez pensar numa das alternativas encontradas por compositores que vivenciaram as

\footnotetext{
${ }^{6}$ Marionilde Magalhães detalha que o SNI foi criado em 1964 e subordinou, rapidamente, vários outros órgãos repressivos. Para integrá-los e "harmonizar" suas ações, foi criado o Destacamento de Operações de Informação - Centro de Operações e Defesa Interna (DOICODI), instituição oficializada em 1970, que aglutinava todas as demais forças policiais (MAGALHÃES, 1997).

Durante os anos 1960, Tony Tornado passou uma temporada no bairro do Harlem, em Nova Iorque. Lá, conviveu com membros dos Partidos dos "Panteras Negras" e com líderes do Movimento pelos Direitos Civis nos Estados Unidos, como Stockley Carmichael.
} 
imposições da ditadura militar no Brasil: "camuflar" determinados signos para "driblar" os órgãos de Censura ${ }^{8}$. No dia da apresentação de Tony Tornado no palco V FIC representantes do governo estavam atentos, pois temiam que ele pudesse fazer uma homenagem ao Black Power, afinal, todos sabiam (e a imprensa noticiava com frequência) que Tornado havia passado vários meses nos Estados Unidos e que teria conhecido os principais líderes dos "Panteras Negras".

Entre 1971 e 1972, Tony Tornado gravou seus dois LP's e alguns Compactos Simples, entre estes, destacamos "Sou Negro", nome do compacto gravado pela Odeon em 1970 e, também, título da principal canção do disco .

Imagem 6 - Capa do Compacto Simples "Sou Negro"

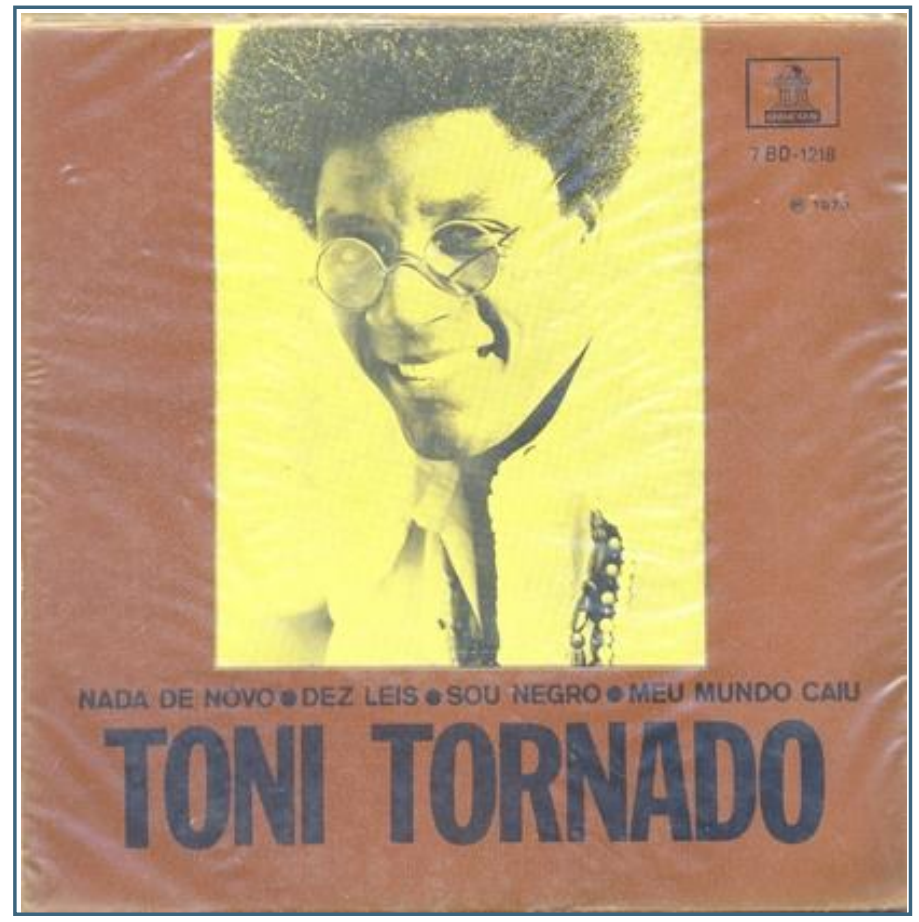

Fonte: SOU..., 1970

\footnotetext{
${ }^{8}$ Reconhecemos que a literatura produzida acerca desse período específico de nossa história é vasta e diversa. No entanto, me alinho àquela que defende ter havido no Brasil um golpe civilmilitar-empresarial. Para Marcelo Badaró Mattos, nos anos 1980, "surge a mais abrangente e significativa análise sobre as articulações entre setores das classes dominantes e militares, resultando no golpe de 1964, escrita por René Dreifuss" (MATTOS, 2008, p. 247). Em suas análises sobre o golpe, a questão da classe ganha força e é primordial. Nas palavras de Dreifuss "As classes dominantes, sob a liderança do bloco multinacional e associado empreenderam uma campanha ideológica e político-militar em frentes diversas, através de uma série de instituições e organizações de classe, muitas das quais eram parte integrante do sistema político populista" (DREIFUSS, 1981, p. 483).

${ }^{9}$ Canção disponível em: https://www.youtube.com/watch?v=cN-NSLBOrvw Acesso em: 08 jul. 2020. "Sou Negro" também é uma das faixas do disco "Good God! Heavy funk covers of James Brown from all over the world 1968-1974”. Guerrilla Reissues, de 2007.
} 
Ao interpretar "Sou Negro" (Getúlio Côrtes - Ed Wilson) em programas de televisão daquela época, Tony Tornado costumava erguer o punho para o alto, fazendo alusão ao gesto característico dos "Panteras Negras". Além disso, a mensagem inscrita nos versos da canção não pode ser negligenciada, como podemos observar:

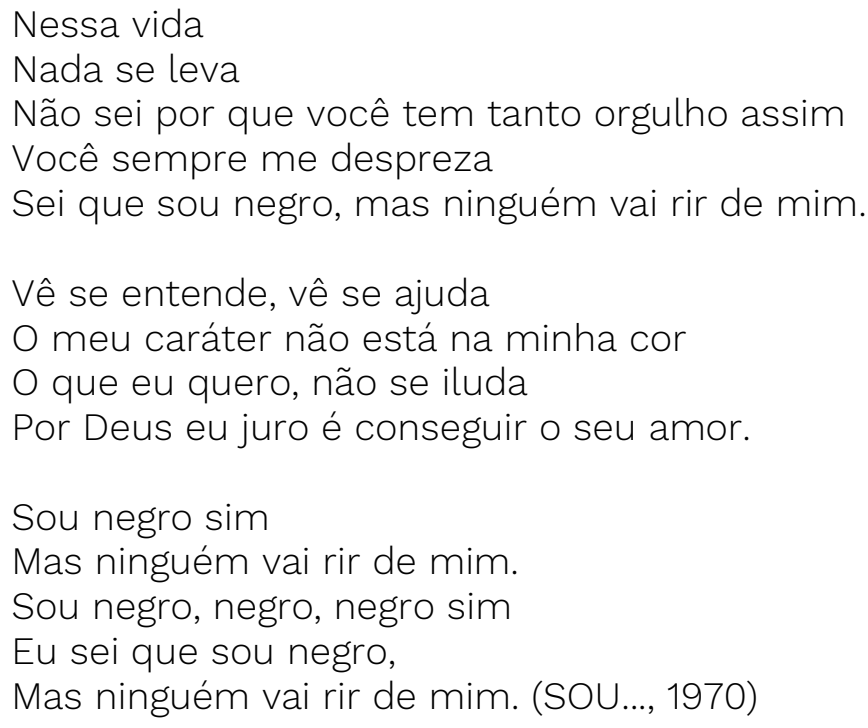

Várias revistas consultadas informam que essa seria a "canção de protesto” de Tony Tornado. A interpretação do músico e versos-chave da canção, como "Sou negro sim, mas ninguém vai rir de mim" se destacam. Uma notícia publicada na Revista Veja em sete de outubro de 1970 informa que:

Ao interpretar na televisão carioca a canção 'Sou Negro', cuja letra focaliza problemas de raça, o cantor Tony Tornado foi advertido pelo Serviço de Censura na última semana por acompanhar sua interpretação com tapas no rosto e gestos de punho cerrado, imitando os representantes do Poder Negro dos Estados Unidos. Motivo da advertência: Tony Tornado (apelido do carioca Antônio Vieira Gomes) dá uma imagem falsa da realidade brasileira, ao insinuar agressivamente um clima de ódio racial que não existe no Brasil. (GENTE..., 1970, p. 84)

Chamou-nos a atenção, incialmente, o trecho: "[...] foi advertido pelo Serviço de Censura por acompanhar sua apresentação com tapas no rosto e gestos de punho cerrado". Ora, na esteira de Paul Zumthor, compreendemos que “o intérprete significa” (ZUMTHOR, 2001, p. 228), destarte, todos os tipos de interpretações serão sempre "portadoras de sentido", afinal, "interpretar implica também compor" (PARANHOS, 2000, p. 224): 
Inevitavelmente, quando alguém canta e/ou apresenta uma música sob essa ou aquela roupagem instrumental, atua igualmente, num determinado sentido, como compositor. O agente opera, em maior ou menor medida, na perspectiva de decompor e/ou recompor uma composição. (PARANHOS, 2004, p. 25)

Assim, a performance de Tornado ("agressiva" segundo a revista), estapeando a própria face ao repetir os enunciados "Sou negro sim, sou negro sim, mas ninguém vai rir de mim", nos auxilia nas evidências de sentido produzidas a partir de sua interpretação, e nos conduzem a pensar na própria condição do sujeito negro brasileiro, naquele período.

Com base na sequência discursiva, na qual a revista informa que o motivo da advertência foi porque o cantor "dá uma imagem falsa da realidade brasileira, ao insinuar agressivamente um clima de ódio racial que não existe no Brasil", identificamos que o grande receio era de que o cantor questionasse o discurso de "democracia racial", tão propagado naquele período10 ${ }^{10}$ Sobre o assunto, não poderíamos deixar de comentar que o sociólogo brasileiro Florestan Fernandes problematizou a noção de "tolerância racial" em nosso país e abordou, em seus livros, a temática, priorizando a questão da desigualdade. Em sua obra "A integração do Negro na Sociedade de Classes” (1978), Florestan Fernandes evidencia a constituição problemática da cidadania decorrente da marginalização social do negro e da persistência da antiga ordem patrimonial na sociedade brasileira, e analisa o que chamou de "mito da democracia racial" (MDR), entendido como ideologia que dificulta o reconhecimento do racismo e da discriminação na sociedade brasileira (FERNANDES, 1978). Ao discutir as bases da construção do MDR, Fernandes explica que o referido mito permite uma representação ilusória da situação do negro no Brasil, uma contradição entre a ordem jurídica e a sua real situação na sociedade, além de se tratar de uma técnica e ideologia de dominação imposta pelas elites aos demais segmentos sociais. Para Ronaldo Sales Júnior:

\footnotetext{
10 Em trabalhos anteriores, Alves $(2010 ; 2014)$ discutiu essa questão ao demonstrar que as apresentações de Tony Tornado em programas de TV e em festivais de música causaram agitação e, de certa forma, passaram a representar uma "ameaça" para a sociedade brasileira, na medida em que se ponderava a possibilidade de que ele viesse a se tornar um "líder negro", capaz de facilitar a formação de organizações políticas no Brasil, como a dos "temidos" "Panteras Negras".
} 
O Mito da Democracia Racial é constituído por uma forma dramática que sintetiza o processo de formação de uma vontade coletiva como "povo" ou "nação" brasileira, fantasia concreta que atua sobre uma multiplicidade heterogênea, segmentada e estratificada. Através do "mito das três raças", o novo bloco dominante tornou-se hegemônico, alcançando a capacidade prática e imaginaria de transcender o horizonte de uma determinada classe ou grupo social, interpelando, assim, uma vontade coletiva nacional-popular, como protagonista de um efetivo drama histórico: o povo brasileiro, fruto da miscigenação, do sincretismo, da mistura cultural. (SALES JÚNIOR, 2006, p. 173)

A democracia racial - exaltada como modelo e elemento essencial na formação da sociedade brasileira - foi uma das principais ideologias propagadas pelo regime militar brasileiro, a partir de 1964 (GUIMARÃES, 2002). Ao se apoiar naquela ideologia, o regime buscava consolidar uma imagem de nação como "pátria", colocando em prática ideias e propagandas que exaltavam um "Brasil harmônico", também racialmente. Nessa direção, debates e discussões conduzidos pela população negra, sobre sua condição e situação na sociedade brasileira, foram identificados como "indesejáveis" pelo regime político, que taxava como "perigosa" a participação daquela população em movimentos sociais. Porém, após 1964, vários movimentos sociais negros permanecem articulados.

Karin Sant'Anna Kössling, na Dissertação "As lutas antirracistas de afrodescendentes sob vigilância do DEOPS/SP (1964-1983)", detalha a atuação de grupos e movimentos negros durante a ditadura militar e demonstra, através de uma cuidadosa análise de documentos do DEOPS, de São Paulo, como o regime se preocupava em "conter o protesto negro" e "possíveis conflitos raciais". A autora esclarece, ainda, que parte dos movimentos negros, da década de 1970, tinha como uma das principais bandeiras de luta "desmascarar a democracia racial, vista como um empecilho à organização das lutas antirracistas" (KÖSSLING, 2007, p. 80). Nas palavras de Guimarães, "a acusação de que a 'democracia racial' brasileira não passava de 'mistificação', 'logro' e 'mito' toma conta do movimento" (GUIMARÃES, 2002, p. 166). Com o endurecimento do regime militar, a partir de 1968, as principais lideranças políticas e membros da intelectualidade negra brasileira estavam no exílio. Mesmo assim, grupos importantes, como o Teatro Experimental do Negro (TEN), continuaram atuantes. 
Mesmo exilado, Abdias Nascimento denunciava o racismo brasileiro em palestras e fóruns realizados em diversos países do mundo. Na década de 1970, valores vigentes foram questionados em diferentes espaços: nas políticas alternativas, na literatura e na música. Naquele período, surge o Movimento Negro Unificado, que, ao lado de outras organizações, foi fundamental no questionamento das formas tradicionais de poder, ao demonstrar "o lado mítico da democracia racial", tão exaltada enquanto modelo, porém, distante da realidade brasileira (SCHWARCZ, 1998, p. 205-208). Assim, qualquer manifestação contrária à ideia de "harmonia racial" no Brasil, poderia estar sujeita à coerção.

Ao ser questionado pela revista "Aconteceu" (1970) acerca do "punho cerrado para o alto" ao interpretar a canção "Sou Negro", Tony Tornado afirmou:

A censura implicou com sua saudação de punho erguido em Sou Negro Sim, vendo nela um gesto de pura violência dos panteras negras. "Era um gesto que eu fazia sem nenhuma maldade. Imitava o Pelé que, quando faz um gol, esmurra o ar. Achei isso muito bacana e coloquei em termos musicais" - explica ele. (O SOUL..., 1970, p. 23, grifos do autor)

Atentemos para a sequência discursiva: "Era um gesto que eu fazia sem nenhuma maldade. Imitava o Pelé que, quando faz um gol, esmurra o ar”. Durante o nosso percurso, vimos que não devemos considerar a linguagem algo transparente e neutro, pelo contrário, características históricas e sociais devem ser consideradas nas análises dos diferentes discursos produzidos e, nessa direção, torna-se capital compreendermos que condições sociais e históricas fazem com que as palavras tenham significados diferentes, pois estão vinculadas a redes de significados específicos (ROCHA; DEUSDARÁ, 2011, p. 169). Conforme já afirmamos, estamos trabalhando com um período de nossa história em que a "democracia racial" era exaltada como um modelo de nossa sociedade e, questionar tal modelo, poderia ser "perigoso", tendo em vista a repressão e o cerceamento impostos pela ditadura. Devemos nos atentar, ainda, para as modificações na materialidade do texto, como esclarecem Cristina Giorgi e Bruno Deusdará:

É possível orientar as análises no sentido de também buscar os efeitos produzidos pelo emprego de recursos gráficos diversos, que contribuem para a inserção de comentários atribuídos ao 
enunciador e contribuem para a construção de efeitos diversos. (GIORGI; DEUSDARÁ, 2019, p. 70-71)

Assim, o negrito utilizado na escrita dos enunciados "Sou negro sim" e “panteras negras” são marcações no texto que contribuem para a produção dos efeitos de sentido que, naquele caso, remetem/podem remeter à relação entre a canção interpretada por Tony Tornado e o "violento" grupo político estadunidense, "panteras negras".

Durante nossas investigações, tivemos acesso a pareceres do Centro de Informações do Exército (CIE), entre eles, um documento de cinco páginas, cujo título é "FLÁVIO CAVALCANTI, TONY TORNADO e DANUSA LEÃO TENTAM SUSCITAR O PROBLEMA DA DISCRIMINAÇÃO RACIAL NO BRASIL"11. O documento é dividido em quatro partes, sendo: 1. ASSUNTO; 2. ASPECTOS GERAIS; 3. ANTECEDENTES; 4. CONCLUSÃO. Num primeiro momento, é interessante notarmos que até mesmo um dos programas mais "populares" da TV brasileira naquela época, como o programa de auditório de Flávio Cavalcanti, poderia despertar algum tipo de "desconfiança" entre os militares. Na seção "ASSUNTO", do parecer, consta que o Programa "pela segunda vez" "tenta suscitar o problema da discriminação racial no BRASIL". Em seguida, na parte relativa aos "ASPECTOS GERAIS", temas como "as esquerdas no BRASIL" e "movimento subversivo" são relacionados ao assunto geral do documento, ou seja, "o problema da discriminação racial do BRASIL":

As esquerdas no BRASIL, unidas ao movimento subversivo, vêem realizando sucessivas tentativas para agitar o ambiente nacional [...]. Apesar dessas investidas, repudiadas por toda a Nação, há equilíbrio e tranquilidade; mesmo assim, são perigosas e altamente desfavoráveis, porquanto acirram descontentamentos, provocando áreas de atrito na sociedade em torno de assuntos ultrapassados ou inaceitáveis no atual estágio de nosso desenvolvimento. (BRASIL, 1971, sem paginação)

\footnotetext{
${ }^{11}$ MINISTÉRIO DO EXÉRCITO - CENTRO DE INFORMAÇÕES DO EXÉRCITO (CIE). S/103.2, dez. 1971. Arquivo Nacional de Brasília. Documento cedido pelo Professor Dr. Alexandre Felipe Fiúza, a quem agradecemos o desprendimento e a gentileza acadêmica. Durante o golpe civil-militarempresarial, o Serviço Nacional de Informação (SNI) era um órgão subordinado ao presidente da República e deveria fornecer a ele informações que o auxiliassem na tomada de decisões. Em cada ministério havia um setor encarregado de também obter dados: as Divisões de Segurança e Informações (DSI). Nos ministérios militares, esses setores assumiram nomes especiais. Havia o Centro de Informações do Exército (CIE), o Centro de Informações da Marinha (CENIMAR) e o Centro de Informações de Segurança da Aeronáutica (CISA).
} 
Em nossa busca pelos efeitos na produção de sentidos, negamos qualquer "transparência" da linguagem e analisamos os diversos discursos pela historicidade que os constituem. Sob essa perspectiva, o sujeito do discurso, inscrito na linguagem, sempre estará atravessado pelo lugar de onde fala. Ao incluirmos no corpus da pesquisa pareceres da Censura produzidos, particularmente, pelo Centro de Informações do Exército, não podemos deixar de considerar aquelas assertivas. Desse modo, nos perguntamos: qual o papel destinado ao censor? Como esse agente atua sobre o discurso? Ele deixa marcas no discurso? Como o sentido é construído?

$\mathrm{Na}$ análise das sequências discursivas (presentes no parecer do ClE), verificamos que lealdade e dedicação são características presentes e recorrentes, também, em outros documentos produzidos pelos órgãos do Estado durante a ditadura militar no Brasil, haja vista que a "manutenção da ordem" era uma das principais tarefas destinada aos censores. Em segundo plano, devemos nos atentar para marcações no texto, como sublinhados, parênteses e palavras escritas em caixa alta, pois todas essas marcas contribuem para a produção de sentidos. Nos pareceres consultados, por exemplo, as designações "BRASIL", "TONY TORNADO" e "BR-3" são escritas em caixa alta, assim como, as expressões “BLACK POWER", "PRECONCEITO RACIAL” e “DISCRIMINAÇÃO RACIAL”.

Durante a ditadura militar era importante propagar um "clima de harmonia social” e, no fragmento do parecer, destacado anteriormente, os enunciados "esquerdas do BRASIL" e "movimento subversivo" são os grandes responsáveis em gerar "atrito" no "tranquilo" e "equilibrado" ambiente nacional. Na sequência discursiva, notamos que a direção dos sentidos aponta para um imaginário social, em que as "esquerdas" e o "movimento subversivo", presentes no BRASIL, seriam uma ameaça à nossa tranquilidade, algo, aliás, "repudiado por toda a Nação". A questão central gira em torno de "assuntos ultrapassados ou inaceitáveis no atual estágio de nosso desenvolvimento”, ou seja, a discriminação racial no BRASIL.

A seção destinada aos "ANTECEDENTES" está dividida em quatro fases. Na primeira delas, verificamos certa preocupação com a "imagem do Brasil" no exterior, haja vista que "Um programa de televisão da BBC de Londres [...] buscou macular nosso País apresentando, com destaque calunioso, numa suposta 
discriminação racial” (BRASIL, 1971, sem paginação). Logo abaixo, o parecer elenca uma série de acontecimentos que vinham "corroborando com essa infame calúnia”. Atentemos para o seguinte trecho:

[...] dia 25 Ago 70, 5a feira - Programa "Alô Brasil aquêle abraço", TV GLOBO, Canal 4 - Rio, marca a presença do Cantor negro TONY TORNADO, que voltara dos Estados Unidos, interpretando uma canção de protesto do negro americano contra a discriminação racial existente em nosso país, com o lançamento inédito do gesto-símbolo do "poder negro" (comunista), êste representado pelo punho direito cerrado, braço estendido para o alto (BRASIL, 1971, sem paginação, grifos do autor).

Sabemos que durante a ditadura militar foi construído um imaginário que retratava o "comunismo" e os "comunistas" como representações do "mal", do "caos" e da "desordem". Além disso, a permanência de "comunistas" no Brasil traria consequências ruins, como fome, miséria e violência. Esse imaginário, carregado de marcas negativas, está presente nos discursos e enunciados produzidos pelos órgãos de censura, que buscavam legitimar as ações de combate aos "inimigos comunistas". Nessa perspectiva, "se definiu, como sendo comunismo, todas as manifestações de oposição ao regime militar e de livre pensamento" (D’ARAÚJO; SOARES; CASTRO, 1994, p. 30). Esse foi o caso dos movimentos negros, que passaram a ser vistos como mais um elemento da ação comunista em nosso país (KÖSSLING, 2007), como podemos verificar no enunciado grifado, "gesto-símbolo do poder negro" (comunista), que teria sido lançado no Brasil por Tony Tornado. Nessa direção, gostaríamos de destacar uma matéria de capa, publicada no jornal "Folha da Tarde" no dia 1o de abril de 1971. Infelizmente, não tivemos acesso ao jornal impresso ${ }^{12}$, e não foi possível fazermos uma leitura da notícia sobre Tony Tornado, porém, é possível levantarmos algumas questões a partir do material que temos. Em primeiro lugar, chamou a nossa atenção o modo como as notícias e as imagens estão dispostas na capa do jornal, cujo enunciado "POVO METRALHADO PELOS BANDIDOS DA SUBVERSÃO" (POVO..., 1971, sem paginação) é destacado e, logo abaixo, é inserida a imagem de Tornado acompanhada do enunciado, escrito em letras bem

\footnotetext{
${ }_{12}$ Material disponível em: http://www.editora3estrelas.folha.uol.com.br/primeiraleitura/16663-aguinada-ideologica-da-br-ifolha-da-tarde-i.shtml_Acesso em: 08 jul. 2020.
} 
menores: "PRESO TONY TORNADO" (POVO..., 1971, sem paginação). Essas questões são importantes, pois contribuíram para a compreensão dos efeitos de sentido. Vejamos a capa do jornal:

Imagem 7 - "PRESO TONY TORNADO"

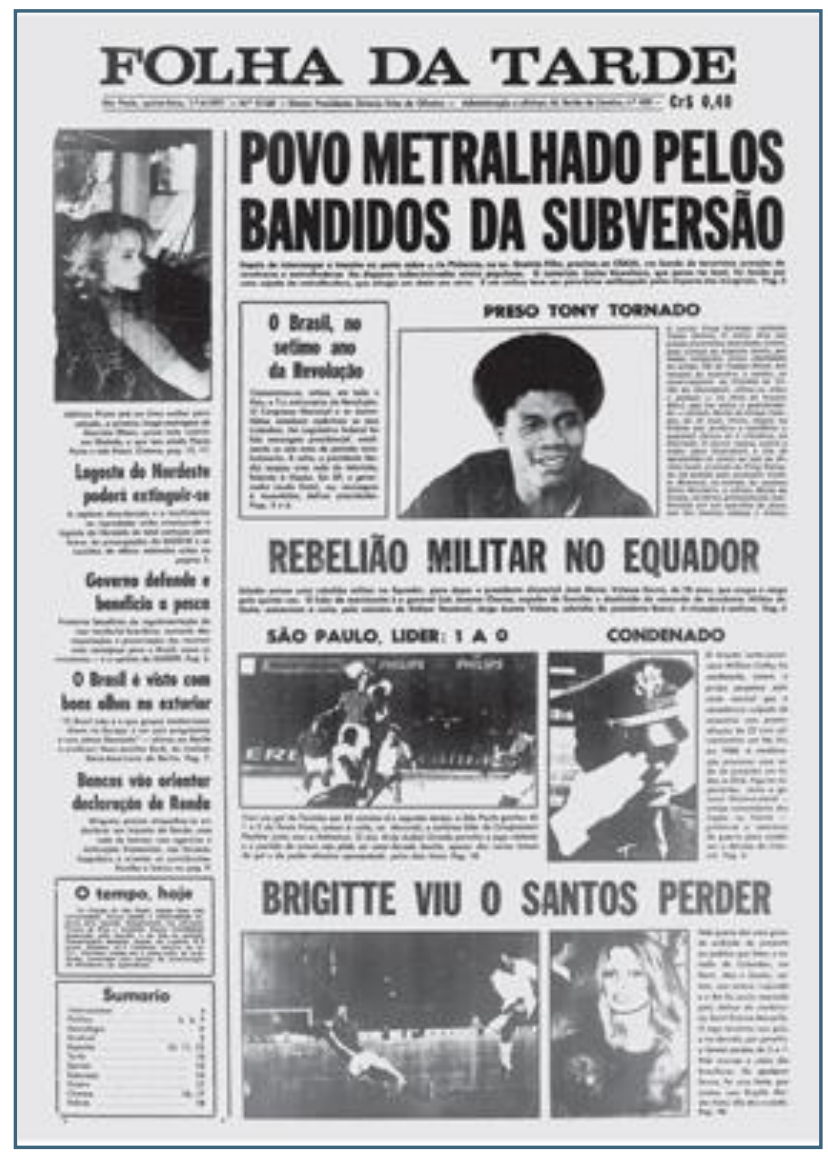

Fonte: POVO..., 1971, sem paginação.

Pudemos notar, apesar da dificuldade na leitura, que o enunciado sobre os “BANDIDOS DA SUBVERSÃO" faz referência a uma reportagem inserida no interior do periódico e, na pequena descrição da reportagem, não identificamos menção alguma a Tony Tornado. Ou seja, o posicionamento dos textos inseridos na capa do jornal contribui, no nível do discurso, para que efeitos de sentido fossem produzidos e, naquele caso, contribuíram para que a imagem de Tony Tornado fosse associada aos "BANDIDOS DA SUBVERSÃO"13. Sabemos, ainda, que as

\footnotetext{
${ }^{13}$ Em um parecer do CIE, datado em 17 de outubro de 1972, lemos: "Enquanto um quadro destrói a imagem de ídolos populares e culturais do Brasil, outro procura substituí-los por artistas ideologicamente contrários ao regime e à formação cristã de nosso povo. Nesse confronto [...] são promovidos VINÍCIUS DE MORAIS, CHICO BUARQUE DE HOLANDA, MARÍLIA MEDALHA,
} 
matérias de primeira página tendem a se transformar em notícias de interesse do leitor, independentemente de seus interesses particulares. Do mesmo modo, assuntos pouco relevantes podem catalisar a atenção do leitor, simplesmente, por estarem na primeira página. Além dessas questões, julgamos fundamental questionar: a qual comunidade o texto está sendo apresentado?

A "Folha da Tarde", periódico paulista lançado em outubro de 1967, era considerada o "porta-voz da ditadura", ao legitimar atos do regime, como repressão e tortura e, entre os anos de 1969 e 1974, angariou altos números de vendagem na cidade de São Paulo. Cleofe Monteiro de Sequeira explica que "a angulação dada às notícias tinha um ponto básico: tratar como inimigo da pátria quem se opunha ao governo" (SEQUEIRA, 2004, p. 05) e, para isso, os editores introduziam, no lead, enunciados "fortes", que pudessem causar impacto. Em se tratando da "Folha da Tarde" aqueles critérios estavam fortemente associados ao contexto político e ideológico daquele período. Sobre isso, a autora complementa:

O jornal se diferenciava também pela terminologia e pela angulação que dava às informações, principalmente as relacionadas com o combate à guerrilha, elaboradas visivelmente para apoiar o regime militar. A terminologia e a angulação usadas na construção da notícia na FT funcionavam como o editorial do jornal (que não tinha página de opinião), mostrando a posição política. (SEQUEIRA, 2004, p. 03)

Em nome da Segurança Nacional, um complexo sistema repressivo de combate à subversão e "perturbação da ordem" foi instalado no Brasil. Ao comparar registros, cartas e pareceres, Marionilde Magalhães detectou várias semelhanças em seus procedimentos que revelavam, nas entrelinhas, diversos

MARCOS VALE, MPB-4, TONI TORNADO, TOM JOBIM, GAL COSTA, GILBERTO GIL e outros; todos de esquerda e contrários à Revolução de 64" (BRASIL, 1972, sem paginação). Interessante notamos que do mesmo modo que Chico Buarque, Caetano Veloso e Gilberto Gil, Tony Tornado é visto como um "artista ideologicamente contrário ao regime e à formação cristã do povo". O parecer, ainda, insere o cantor como sendo de "esquerda e contrário à Revolução de 64". Como destaca Karin Kössling (2007), com frequência, o golpe de 1964 se apresentava na documentação do DEOPS com a seguinte frase carimbada: "A revolução de 64 é irreversível e consolidará a Democracia no Brasil". A ideia de "revolução", e suas representações positivas a partir do golpe, objetivava angariar legitimidade. Ademais, como esclarece Kössling, "foi necessário para o regime reafirmar e glorificar a "revolução" ao longo de seus governos, até mesmo para os funcionários da repressão” (KÖSSLING, 2007, p. 32). 
preconceitos, entre eles, o preconceito racial, em que o negro é sempre descrito como "desordeiro" (MAGALHÃES, 1997). Como bem demonstrou Lucas Pedretti Lima na Dissertação de Mestrado "Bailes soul, ditadura e violência nos subúrbios cariocas na década de 1970", através da documentação policial e militar, podemos conhecer um pouco mais a "visão" das instituições de vigilância e repressão brasileiras, especialmente, acerca dos chamados "desordeiros" e "perturbadores da ordem", sendo que os afrodescendentes são sempre identificados a priori, como "sujeitos suspeitos" (LIMA, 2018).

Voltemos ao documento do CIE. A introdução, "inédita”, de gestos políticos, como estender o braço com o punho cerrado para o alto, poderia ameaçar o "equilíbrio" e a "tranquilidade" em nosso país e, na sequência discursiva do parecer, aquela ameaça parecia estar simbolizada na figura do "cantor negro TONY TORNADO, que voltara dos Estados Unidos, interpretando uma canção de protesto do negro americano". Provavelmente, a "canção de protesto", mencionada no parecer, é a canção “Sou Negro”, composição de Getúlio Côrtes e Ed Wilson. Além disso, é importante frisarmos que, naquele momento, a imprensa noticiava a expansão de grupos políticos, como os "Panteras Negras", enfatizando o caráter violento de suas ações e descrevendo a luta pelos direitos civis nos Estados Unidos com grandes doses de sensacionalismo.

O caso da TV Globo - citada no parecer - exemplifica a complexidade no campo da censura ${ }^{14}$ de diversões públicas ${ }^{15}$. Carlos Fico nos ajuda a melhor compreender essa questão, ao distinguir censura da imprensa e censura das diversões públicas: os telejornais da emissora não estavam adstritos à Divisão de Censura e Diversões Públicas (DCDP). Eles colaboravam com o regime ou apenas acatavam as proibições determinadas para toda a imprensa, porém, as novelas,

\footnotetext{
${ }^{14}$ Carlos Fico detalha que, durante o Regime Militar brasileiro, não houve uma censura, mas, sim, duas: a censura da imprensa e a censura de diversões públicas. A segunda, antiga e legalizada, existia desde 1945, sendo familiar aos produtores de teatro, de cinema, aos músicos e a outros artistas. Era praticada por funcionários especialistas (os censores) e se amparava numa tradição de defesa da moral e dos bons costumes (FICO, 2004).

${ }^{15}$ Alexandre Fiúza nos explica que até 1968 a censura foi regida pelo Decreto no 20.493, de 1946, criador do Serviço de Censura de Diversões Públicas (SCDP). Entretanto, com a Constituição imposta à população, em 1967, formou-se uma "estrutura de censura" para todo o país. Com tal mudança, a Polícia Federal passou a responder, a partir de 1969, pelos serviços de diversões públicas, mas o artigo 41, do referido Decreto, continuou sendo referência para os censores durante toda a década de 1970 (FIÚZA, 2006).
} 
os programas de auditório e os shows musicais eram cuidadosamente acompanhados pela censura de diversões públicas. No que se refere às novelas e aos seriados, por exemplo, a sistemática implantada pela ação censória exigia que as sinopses fossem analisadas pela DCDP e, antes da elaboração dos capítulos, a emissora recebia recomendações sobre temas a serem evitados, comportamentos que poderiam gerar cortes e assim por diante (FICO, 2002).

A seguir, o documento informa sobre outras apresentações de Tony Tornado em programa de TV da época: no dia 29 de agosto de 1970, no Programa “Aerton Perlingeiro Show", na TV TUPY - Rio de Janeiro e, em 30 de agosto, do mesmo ano, no Programa de Flávio Cavalcanti, também na TV TUPY. Em ambos os programas, um dos assuntos seria "sua canção de protesto e o seu gesto". De acordo com o informante, tratou-se de uma "sequência perigosa", mas, “contornada após algumas ligações diretas com os diretores da [...] TV TUPY”. A consequência teria sido: "A TV TUPY advertiu o cantor TONY TORNADO proibindoo de repetir o gesto do 'poder negro' mesmo ao cantar a canção de protesto" (BRASIL 1971, sem paginação). Entretanto, como informa o parecer:

Mesmo assim, no sábado 5 Set 70, no programa da Ziza ("Aerton Perlingeiro Show"), o cantor TONY TORNADO, repetiu a canção e o gesto, apesar de advertido pela apresentadora diante do vídeo. Essa insistência do cantor foi motivo de proibição de sua entrada na TV TUPY, que foi relaxada consequente promessa do mesmo e de seus empresários - os compositores Tibério Gaspar e Antônio Adolfo, e do "Conjunto Brazuca", de que a canção e o gesto não seriam mais repetidos pelo cantor. (BRASIL 1971, sem paginação)

Nessa sequência discursiva, enunciados descritos nas seções anteriores, como "canção de protesto" e "gesto político" são retomados ao destacarem a insistência do músico em cantar a "canção de protesto" e repetir o mesmo "gesto", agora, no programa da Ziza. Aliás, a performance que o músico exibiria no palco do V Festival Internacional da Canção era uma grande preocupação para os censores, como podemos observar na segunda fase dos ANTECEDENTES. Nessa seção, o seguinte trecho nos chamou a atenção: 
[...] tôda máquina policial se movimentou nos bastidores do Maracanãzinho para impedir os gestos de caráter político do cantor e, também, para proibir o uso de tóxicos e entorpecentes que, segundo denúncias, eram utilizados pelos concorrentes, inclusive TONY TORNADO. Apesar da celeuma criada em torno da canção "BR-3" e do cantor de que representam a hegemonia dos viciados em entorpecentes, foi o problema contornado. (BRASIL 1971, sem paginação)

Identificamos o interdiscurso do censor, quando este faz referência ao "caso Ibrahim Sued", já narrado anteriormente. Interessante notar, aliás, que antes mesmo da canção "BR-3" ser defendida no V FIC, já havia comentários de que a letra seria uma alusão ao uso de drogas: "Apesar da celeuma criada em torno da canção "BR-3" e do cantor de que representam a hegemonia dos viciados em entorpecentes, foi o problema contornado". A sequência discursiva "tôda máquina policial se movimentou nos bastidores do Maracanãzinho para impedir os gestos de caráter político do cantor" também nos chamou atenção, pois indica que o Centro de Informações do Exército estava atento ao evento, e parecia que um dos focos de preocupação era, precisamente, Tony Tornado.

A quarta e última fase dos ANTECEDENTES faz referência a participações de Tony Tornado no programa de Flávio Cavalcanti nos dias 11 e 19 de abril de 1971:

Com a finalidade aparente de socorrer o cantor TONY TORNADO, Flávio Cavalcanti, no seu programa de 11 Abr 71, torna a apresentálo com destaque, denotando intenções provocativas e de contestação às medidas adotadas pelas autoridades. [...] 0 comportamento de TONY TORNADO tentando lançar o movimento do "poder negro" americano no BRASIL está em exame, notadamente os seus reflexos sobre a juventude negra de nosso País. (BRASIL 1971, sem paginação)

Gestões foram feitas junto à TV TUPY mostrando a gravidade do problema, mesmo assim a propaganda para o "Programa de Flávio Cavalcanti" do domingo 18 Abr 71 foi feita com a repetição exaustiva de apresentação do TONY TORNADO, ao que parece a título de provocação às autoridades. (BRASIL 1971, sem paginação)

A primeira sequência discursiva enuncia que o comportamento de Tony Tornado será examinado, especialmente, por conta de "seus reflexos sobre a juventude negra de nosso país". O enunciado do parecer nos leva a refletir sobre os sentidos atribuídos à figura de Tony Tornado naquele período, principalmente, 
após ele vencer o V FIC, pois, como já destacamos, ele simbolizava um movimento musical novo, jovem e dançante, que se fortalecia entre nós, mas, expressava, também, uma estética e uma postura peculiares.

Mais adiante, são apresentados alguns possíveis fatos que comprovariam as atitudes, reprovadas, do apresentador Flávio Cavalcanti: "5) o problema da discriminação racial levantado duas vezes no seu programa, utilizando o mesmo cantor, TONY TORNADO". No final do parecer foi destacado, ainda, que no "Programa Silvio Santos", do domingo de 18 de abril de 1971, pela TV Globo - São Paulo, o cantor brasileiro Antônio Marcos “fez o gesto do 'poder negro', gesto este enfocado repetidamente pelo 'câmera-man', com imagem ocupando toda tela dos televisores". É mencionado, ainda, que todos os fatos narrados "denotam uma sequência em cadeia bastante perigosa” e, finalmente, na seção CONCLUSÃO é destacada a gravidade da situação, cuja solução "escapa às atribuições do Ministério de Exército", mas aponta para a "necessidade urgente de que sejam advertidos severamente os seguintes artistas e televisões: Flávio Cavalcanti, Danusa Leão, Tony Tornado, Antônio Marcos, Televisão Tupy/Rio e Televisão Globo/São Paulo" (BRASIL 1971, sem paginação). Com relação a Tony Tornado e Antônio Marcos ainda é feita a seguinte recomendação: "deverão, ainda, ser admoestados para não repetirem o gesto do 'poder negro', o que poderia conduzir a uma suspensão definitiva dos mesmos diante das câmeras de televisão".

Em sua Dissertação, Lucas Pedretti Lima (2018) informa que o Centro de Informações de Segurança da Aeronáutica (CISA) também fez referência a Tony Tornado em alguns de seus documentos. O autor descreve um relatório produzido pelo CISA, no qual, sem mencionar o nome do artista, descreve a “apresentação de um cantor com uma música alusiva ao problema racial” no Programa de Flávio Cavalcanti, no início dos anos 1970. O documento segue, discutindo a publicação de textos na imprensa alusivos à questão do "RACISMO, PRECONCEITO RACIAL E DISCRIMINAÇÃO RACIAL” no Brasil:

A publicação pela imprensa de artigos, pesquisas, análises, debates e pronunciamentos de quem quer que seja sobre preconceito e discriminação racial, só servirá para criar um clima 
propício a efervescências e agitações sociais que poderão culminar com a implantação no BRASIL, de distúrbios raciais, a exemplo do que ocorre nos Estados Unidos da América do Norte. (DOCUMENTO DO CISA, [197-] apud LIMA, 2018, p. 77)

Este Centro julga oportuno proibir à imprensa a veiculação de quaisquer notícias, pesquisas, debates, etc. que tenham a ver com "RACISMO", "PRECONCEITO RACIAL", "DISCRIMINAÇÃO RACIAL", etc. Medida paralela também deveria ser tomada quanto a pronunciamento desse assunto por parte de autoridades, professores e religiosos, ou a inclusão de temas raciais nos enredos de novelas radiofônicas ou áudio-visuais, literatura para jovens, novelas em quadrinhos, etc. (DOCUMENTO DO CISA, [197-] apud LIMA, 2018, p. 77)

Além disso, é fundamental percebermos como se constituiu o "fio discursivo" nos pareceres escritos pelos agentes do CIE e do CISA, documentos repletos de sentidos produzidos (e reiterados) sobre Tony Tornado. Ademais, a possibilidade do surgimento de um "poder negro" no Brasil - liderado pelo cantor Tony Tornado - parecia ser uma preocupação concreta para os agentes da ditadura militar. Os enunciados presentes na documentação reiteram a ideia de que o racismo era um assunto ultrapassado entre nós, logo, não haveria necessidade de falar, cantar ou escrever sobre o assunto.

O vínculo do cantor com os "Panteras Negras" ressurgiu durante O VI Festival Internacional da Canção realizado, também, no Rio de Janeiro, em 1971. Como recorda Homem de Mello, o FIC daquele ano estava envolto em várias polêmicas e uma delas foi uma carta enviada à direção do VI FIC - assinada por diversos compositores, entre eles, Paulinho da Viola, Sérgio Ricardo, Tom Jobim, Chico Buarque, Vinícius de Moraes, Toquinho e Edu Lobo, em que anunciavam que não iriam participar do evento devido "a exorbitância, a intransigência e a drasticidade do Serviço de Censura” (MELLO, 2003, p. 403). Entre outros fatos narrados pelo autor de "A era dos festivais" estavam:

Em 1o de setembro, a Polícia Federal determinou que todos os participantes do VI FIC deveriam ser registrados em seus arquivos até uma semana antes do primeiro espetáculo, visando "sanear a área". Seria fornecida uma carteira com nome, identidade oficial, foto $3 \times 4$ e especialidade no FIC (MELLO, 2003, p. 393). 
Pouco antes do VI FIC, a vontade do exército em controlar o festival atingiu as raias do absurdo. Não apenas exigiu que os compositores participantes tivessem a carteira de identidade registrada na Censura, como até os intérpretes e acompanhantes seriam fichados. Uma ficha de cada um deveria ser enviada a Brasília para que os dados fossem checados e emitidas as carteirinhas, que eram então, devolvidas ao Rio (MELLO, 2003, p. 396).

Os órgãos de Censura estavam atentos. Num parecer do CIE, datado em 23 de julho de 1971, lemos:

Agora, o Sr. AUGUSTO MARZAGÃO, prepara uma homenagem ao Poder Negro americano. Pretende trazer um grupo atuante do "BLACK POWER" para se exibir no FIC. É desnecessário falar dos inúmeros problemas criados pelo referido grupo para as autoridades Americanas e, por outro lado, a atuação deste grupo poderá criar uma situação desagradável no trato de um problema que não existe ainda entre nós, que é a discriminação racial. BRASIL, 1971, sem paginação)

O assunto do documento é "FESTIVAL INTERNACIONAL DA CANÇÃO" e pudemos verificar que os agentes estavam preocupados com o evento, pois alegavam que ele poderia suscitar um "problema que não existe ainda entre nós”, ou seja, a discriminação racial. Entretanto, como veremos, os agentes não foram capazes de evitar manifestações nesse sentido.

Como a contagem final dos votos era manual, Elis Regina fez uma apresentação para todos que aguardavam os resultados daquele festival ${ }^{16}$. A cantora interpretou "Black is Beautiful", canção de Marcos Valle e Paulo Sérgio Valle:

\author{
Hoje cedo, na rua do Ouvidor \\ Quantos brancos horríveis eu vi \\ Eu quero um homem de cor \\ Um deus negro do Congo ou daqui \\ Que se integre no meu sangue europeu. \\ Black is beautiful, black is beautiful \\ Black beauty so peaceful \\ I wanna a black, I wanna a beautiful. \\ Hoje a noite amante negro eu vou \\ Enfeitar o meu corpo no teu
}

\footnotetext{
${ }^{16}$ A canção vencedora foi "Kyrie", composição de Paulinho Soares e Marcelo Silva interpretada pelo "Trio Ternura”. Canção disponivel em: https://www.youtube.com/watch?v=iaMrobSGc3E. Acesso em: 08 jul. 2020.
} 
Eu quero esse homem de cor Um deus negro do congo ou daqui

Que se integre no meu sangue europeu

Black is beautiful, black is beautiful

Black beauty so peaceful

I wanna a black I wanna a beautiful (BLACK..., 1971) ${ }^{17}$.

A composição havia sido censurada no ano anterior. Em 1970, os irmãos Valle enviaram a canção para o Serviço de Censura, porém, os censores não a liberaram, pois reprovaram os versos "eu quero um homem de cor/um negro do Congo ou daqui/que melhore o meu sangue europeu” (VALLE, M.; VALLE, P., 1970 apud FERREIRA, 2007) ${ }^{18}$. Ora, como liberar uma canção que julgava o sangue negro melhor que o europeu? Para os agentes da Censura, não havia oposição ou superioridade entre as raças no Brasil, afinal, como já explanamos, naquele período o regime pregava que vivíamos numa "democracia racial". Além disso, como bem destaca Gustavo A. Alonso Ferreira, a canção era ousada ao "inverter a lógica do preconceito racial” (FERREIRA, 2007, p. 77). A canção foi liberada após os músicos fazerem a seguinte mudança em um dos versos:

Hoje cedo, na rua do Ouvidor

Quantos brancos horríveis eu vi

Eu quero um homem de cor

Um deus negro do Congo ou daqui

Que integre o meu sangue europeu. (BLACK..., 1971)

No período em pauta, "a realidade estava deformada pelo regime de exceção; apenas uma parte dessa realidade poderia ser revelada, tudo o mais deveria permanecer silenciado sob os coturnos dos militares" (ROCHA; MENEZES, 2014, p. 76-77). Nessa direção, Décio Rocha e Leila Medeiros de Menezes complementam:

Expressar-se pela escrita era mais ameaçador ainda. Escrever era, sem dúvida, um ato de libertação, de tomada de posição, mas, por outro lado, em relação a seus "interpretantes-censores", que assumiam a função de vigiar os discursos, era um ato altamente subversivo. (ROCHA; MENEZES, 2014, p. 79)

\footnotetext{
${ }_{17}$ Canção disponível em: https://www.youtube.com/watch?v=N3qxP60lZYc. Acesso em: 08 jul. 2020.

18 "Black is Beautiful" (Marcos Valle/Paulo Sérgio Valle). Arquivo Público do Estado do Rio de Janeiro (APERJ). Setor de Diversões Públicas. TN 23.3632 (5/11/1970). Citado por FERREIRA, 2007, p. 76.
} 
Contudo,

ao colocarem as palavras sob suspeita, os censores pretendiam confiná-las aos subterrâneos dos sentidos oficiais permitidos; porém, elas, assumindo sua preciosa liberdade, não se submeteram a consignações e mandatos e explodiram em sentidos outros para além do dito. (ROCHA; MENEZES, 2014, p.82)

As citações dos autores adquirem ainda mais sentido, quando retomamos a ideia de que "interpretar implica também compor" (ZUMTHOR, 2001, p. 228) e que todas as formas de interpretação são "portadoras de sentido" (PARANHOS, 2000, p. 224). Durante a apresentação, Elis Regina virou-se na direção de Tony Tornado que, empolgado, se levantou, subiu no palco, cantou com Elis e cerrou os punhos para o alto. A performance do músico resultou em intimações e depoimentos para a Polícia Federal, como recordou o cantor numa entrevista concedida para a revista Carta Capital, em 2006: "Imagine Elis cantando comigo: 'Hoje cedo, na rua do Ouvidor/Quantos brancos horríveis eu vi/Eu quero um homem de cor'. Eu saí de lá algemado, porque tinha cerrado os punhos durante a música" (TORNADO, 2006, p. 49). A imagem destacada abaixo é um dos raros registros daquele momento:

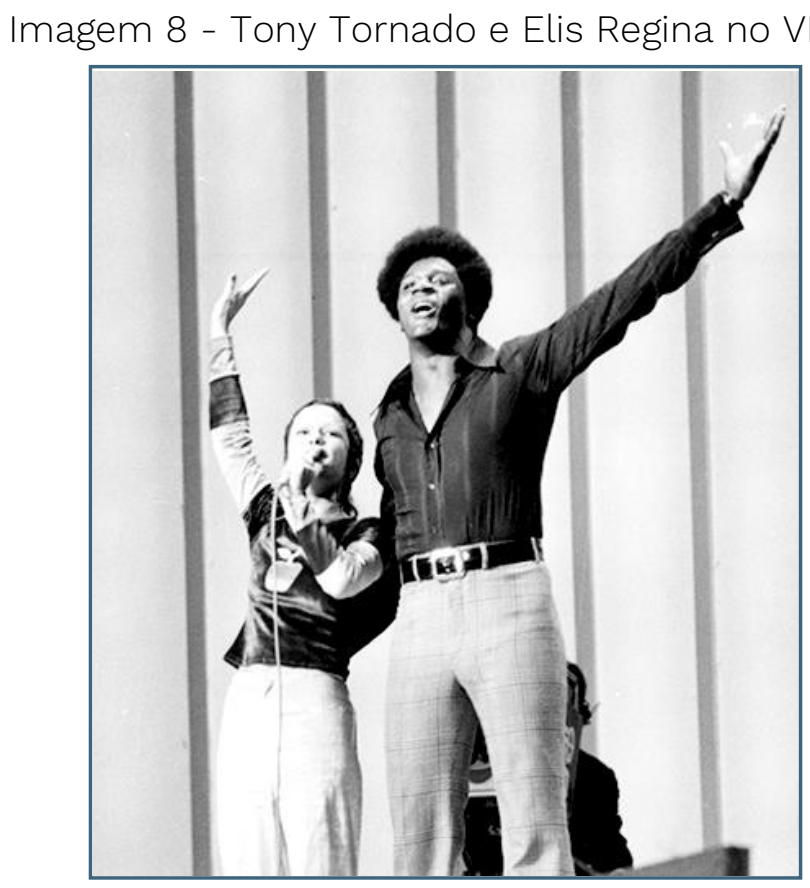

Fonte: [ELIS REGINA E TONY TORNADO]. 1976. 1 fotografia. Disponível em:

https://memoriaglobo.globo.com/wp-content/uploads/2019/10/6\%C2\%BA-FIC-Elis-Regina-TonyTornado-I0000329.jpg. Acesso em: 08 julho 2020. 
A atitude do intérprete de "BR-3" foi destaque em alguns periódicos da época, entre eles, o jornal "Folha de São Paulo" que relatou o fato da seguinte maneira:

Ao Elis cantar Eu quero um homem de cor, ele [Tony Tornado] surgiu com sua cabeleira toda Poder Negro e, de modo muito alienígena lascou um beijo na moça. Como havia artistas estrangeiros, turistas, etc., a coisa fica de um vedetismo absolutamente cafona, pastichando situações de outras terras. (QUANDO..., 1971 apud PAIVA, 2015, p. 110)

Do trecho destacado, chamou a nossa atenção o enunciado "de modo muito alienígena lascou um beijo na moça". Realmente, no país da "democracia racial" era inaceitável um negro beijar uma branca, ainda mais, em público! Ao lermos aquela sequência discursiva, nos lembramos de um caso narrado por Tony Tornado durante a nossa entrevista, em 2009 ${ }^{19}$. Ele nos contou que, ao desembarcar no Rio de Janeiro, no final dos anos 1960, não passou despercebido. Além de usar o cabelo no estilo black power, o cantor trajava um terno amarelo e calçava sapatos coloridos. Tornado foi levado ao DOPS enquanto, ironicamente, os policiais o chamavam de "marciano" (TORNADO, 2009. Informação verbal). O que há em comum entre os enunciados "alienígena" e "marciano"? Sabemos que a soul music (e outros gêneros musicais considerados "importados") era, recorrentemente, chamada de "alienígena” por alguns músicos e compositores da época. Por outro lado, não podemos deixar de perceber os efeitos de sentidos produzidos a partir do uso daquele enunciado num período de nossa história em que o movimento soul se fortalecia e se destacava entre a juventude negra brasileira. Ademais, nas palavras de Tony Tornado, era corriqueiro o chamarem de "marciano", ou seja, alguém cuja humanidade é retirada, pois pertence a outro planeta. O jornalista Júlio Maria, um dos biógrafos de Elis Regina, faz referência ao acontecimento e descreve o que ocorreu logo após, quando Tony Tornado foi levado para a delegacia:

“Então você é o negrão da ‘BR-3’?” perguntou o delegado. “Aquele que dança dando giro?". "Sim, sou eu mesmo". "Então dança um pouco aí pra gente." Toni cantava e fazia todos os passos que sabia. Quando parava, um novo policial aparecia. "Olha só, esse

19 TORNADO, Tony [Entrevista cedida a] Amanda Palomo Alves, Rio de Janeiro, 20 ago. 2009. 
aqui é o Toni Tornado, dança aí pra ele ver", pedia o mesmo delegado. Diante do terror psicológico daquela situação vivida por quase 12 horas, ele recebia um recado: ou baixava a bola ou rasparia seu [cabelo] black power. (MARIA, 2015, p. 224)

Depois da tortura psicológica, o recado estava dado, "ou baixava a bola ou raspariam seu black power" ${ }^{20}$, em outros termos, não seriam admitidas posturas altivas e de afirmação identitária, muito menos, de questionamento do status quo: "Cada um no seu lugar, como sempre foi, e continuaríamos a ser o país da harmonia racial, exemplo para o mundo" (PIRES, 2018, p. 1.076). A ameaça dos policiais adquire novos sentidos, quando consideramos que o cabelo (black power) carregou significados culturais, políticos e sociais importantes naquele período, especialmente, para aqueles vinculados ao movimento soul no Brasil. Além do mais, como ressalta Thula Rafaela Pires:

Quanto mais o regime endurecia, mais cabeleiras orgulhosamente se encrespavam, roupas extravagantes eram expostas [...]. O incômodo que geravam era evidente, não fosse isso não haveria a necessidade de mostrar aos que foram apreendidos [...] a postura que nunca deveriam ter deixado de ter: cabelos raspados, aparência uniforme, olhar desviado para baixo, de preferência, invisíveis. (PIRES, 2018, p. 1.075)

\section{3. À guisa de conclusão}

A análise das sequências discursivas apresentadas, presentes em pareceres da Censura e em periódicos nacionais, nos possibilitou perceber como se deu a produção de sentidos sobre Tony Tornado no período da ditadura militar no Brasil, especialmente, entre os anos de 1970 e 1972. A possibilidade de o artista liderar um movimento negro em nosso país, como o Black Power, parecia ser uma preocupação concreta para os agentes do governo. Vimos que os pareceres da Censura, as revistas e os jornais da época relacionavam, frequentemente, o cantor ao referido movimento e identificamos que um dos grandes receios era de que ele questionasse o discurso de "democracia racial", tão propagado naquele período.

\footnotetext{
${ }^{20}$ Aliás, lembramos, também, que "entre as muitas formas de violência impostas ao escravo e à escrava estava a raspagem do cabelo. Para o africano escravizado esse ato tinha significado singular. Ele correspondia a uma mutilação, uma vez que o cabelo, para muitas etnias africanas, era considerado uma marca de identidade e dignidade (GOMES, 2006, p. 27).
} 
Ao optarmos pela análise do discurso como um importante referencial teórico e metodológico, somamos a escrita deste artigo a outras áreas do conhecimento, que nos auxiliaram em nossa busca pelos efeitos de sentido. Percorrer tal caminho teórico-metodológico nos permitiu reconhecer o uso da língua como prática social, e não como uma simples estrutura (BAKHTIN, 1997). Desse modo, foi possível lermos nos textos "não a expressão de uma vontade estável e individual de dizer, mas as marcas de uma complexa rede de sentidos em embate, que organiza os diferentes modos de ver, pensar e sentir o real" (GIORGI; DEUSDARÁ, 2019, p. 59-60). Além disso, ao compreendermos o racismo enquanto uma categoria discursiva (HALL, 2008; 2015), verificamos que os diferentes meios de comunicação (como a imprensa periódica) são exemplos importantes de reflexão sobre as relações raciais no Brasil, ao produzirem - e reproduzirem - discursos estereotipados sobre a população negra.

Em nossa busca pelos efeitos de sentido, questionamos os enunciados produzidos sobre Tony Tornado e estivemos atentos às estratégias e marcas discursivas presentes nas revistas, nos jornais e nos pareceres da Censura. Nessa perspectiva, nos preocupamos em demonstrar os sentidos atribuídos à sua figura, que nos levaram a compreender que a figura pública do artista brasileiro, Tony Tornado, foi construída, também, com base no racismo.

\section{Referências}

ALVES, Amanda Palomo. O poder negro na pátria verde e amarela: musicalidade, política e identidade em Tony Tornado (1970). 2010. Dissertação (Mestrado em História) - Programa de Pós-Graduação em História da Universidade Estadual de Maringá, Maringá, 2010.

ALVES, Amanda Palomo. Êsse crioulo vai longe: racismo e construções discursivas sobre Tony Tornado na imprensa periódica brasileira (1970-1972). 2019. Dissertação (Mestrado em Relações Étnico-Raciais) - Programas de PósGraduação em Relações Étnico-Raciais do CEFET-Rio de Janeiro, Rio de Janeiro, 2019.

AQUINO, Maria Aparecida de. Censura, imprensa, Estado autoritário (1968-1978): o exercício cotidiano da dominação e da resistência: o Estado de São Paulo e movimento. Bauru: EDUSC, 1999. 
AZEVEDO, Celia Maria Marinho de. Onda negra medo branco: o negro no imaginário das elites-século XIX. Rio de Janeiro: Paz e Terra, 1987.

ANDREWS, George Reid. Democracia racial brasileira 1900-1990: um contraponto americano. Estudos Avançados, São Paulo, v. 11, n. 30, 1997.

A GENTE VENCE NA BR-3. Revista Amiga, Rio de Janeiro, n. 24, p. 03, 3 nov. 1970.

BAKHTIN, Mikhail. Estética da criação verbal. São Paulo: Martins Fontes, 1997.

BAKHTIN, Mikhail. Marxismo e filosofia da linguagem. São Paulo: Hucitec, 2006.

BORGES, Rosane da Silva. Mídia, racismos e representações do outro: ligeiras reflexões em torno da imagem da mulher negra. In: BORGES, Roberto Carlos da Silva; BORGES, Rosane (orgs.). Mídia e racismo. Petrópolis, RJ: DP et Alli; Brasília, DF: ABPN, 2012.

BRASIL. Ministério do Exército. Centro de Informações do Exército (CIE). Flávio Cavalcanti, Tony Tornado e Danusa Leão tentam suscitar o problema da discriminação racial no Brasil. S/103.2. [Brasília: O Ministério, 1971].

BRASIL. Ministério do Exército. Centro de Informações do Exército (CIE). Gabinete do Ministro. [Parecer]. S-103. 2-CIE: Confidencial. Assunto: Programa Flávio Cavalcante; Origem: CIE; Difusão: SNI/AC, DSI/MJ, DSI/MC, DSI/MEC. Rio de Janeiro: Gabinete do Ministro, 17 out. 1972.

BRASIL. Ministério do Exército. Centro de Informações do Exército (CIE). [Parecer n. 146]. S-103. [Brasília: O Ministério], 23 jul. 1971.

BLACK is beautiful. Intérprete: Elis Regina. Compositores: Marcos Valle Paulo Sérgio Valle. In: ELA. Intérprete: Elis Regina. São Paulo: Philips, 1971. 1 disco vinil, lado A, faixa 2 (5 min 20 seg).

CABRAL, Sérgio. O Pasquim, Rio de Janeiro, p. 10, 28 out. 1970.

CÉSAR, Silvio. Êsse crioulo vai longe. Revista Intervalo, São Paulo, n 408, p. 17, 28 out. 1970.

DREIFUSS, René A. 1964: a conquista do Estado. Petrópolis: Vozes, 1981.

D'ARAUJO, Maria Celina; SOARES, Gláucio Ary Dillon; CASTRO, Celso.

(org.) Visões do golpe: a memória militar sobre 1964. Rio de Janeiro: RelumeDumará, 1994.

DOS CABARÉS PARA A GLÓRIA: Tony Tornado, furacão no festival. Revista Intervalo, São Paulo, n. 407, 1970. Capa. 
FERNANDES, Florestan. A integração do negro na sociedade de classes. São Paulo: Ática, 1978.

FICO, Carlos. Versões e controvérsias sobre 1964 e a ditadura militar. Revista Brasileira de História, São Paulo, v. 24, n. 47, p. 29-60, 2004.

FICO, Carlos. Prezada Censura. In: Revista Topoi. Rio de Janeiro, p. 251-286, dezembro de

2002.

FIÚZA, Alexandre Felipe. Entre um samba e um fado: a censura e a repressão aos músicos no Brasil e em Portugal nas décadas de 1960 e 1970. 2006. Tese (Doutorado em História) - Faculdade de Ciências e Letras de Assis da UNESP, Assis, 2006.

FERREIRA, Gustavo A. Alonso. Quem não tem swing morre com a boca cheia de formiga: Wilson Simonal e os limites de uma memória tropical. 2007.

Dissertação (Mestrado em História) - Programa de Pós-Graduação em História da Universidade Federal Fluminense, Niterói, 2007.

FESTA DA VITÓRIA SÓ ACABOU NO DIA SEGUINTE. Revista Intervalo, São Paulo, n. 407, p. 06, 1970.

FIC VALEU PELO MOCOTÓ E ÊSSE INCRÍVEL TORNADO. Revista Intervalo, São Paulo, no 407, p. 02, 1970.

GIORGI, Cristina; DEUSDARÁ, Bruno. ‘É coisa de preto?’ É coisa de branco: um estudo discursivo do racismo na mídia brasileira. In: WIEDEMAR, Marcos Luiz (org.). Estudos linguísticos contemporâneos: questões e tendências. Rio de Janeiro: Editora Autografia Edição e Comunicação Ltda, 2019. p. 35-89.

GOMES, Nilma Lino. Sem perder a raiz. Belo Horizonte: Autêntica, 2006.

GUIMARÃES, Antônio S. Alfredo. Racismo e Antirracismo no Brasil. São Paulo: Ed. 34, 1999.

GUIMARÃES, Antônio S. Alfredo. O insulto racial: as ofensas verbais registradas em queixas de discriminação. Revista de Estudos Afro-Asiáticos, Rio de Janeiro, n. 38, p. 38-41, dez. 2000.

GUIMARÃES, Antônio S. Alfredo. Classes, raças e democracia. São Paulo: Editora 34, 2002.

GENTE. Revista Veja, São Paulo, edição 109, p. 84, 07 out. 1970.

HALL, Stuart. Da diáspora: identidades e mediações culturais. Belo Horizonte: Editora da UFMG: Belo Horizonte, 2008. 
HALL, Stuart. Raça, O Significante Flutuante. Z Cultural: Revista do Programa Avançado de Cultura Contemporânea, Rio de Janeiro, Ano 8, n. 2, 2015.

KÖSSLING, Karin Sant'Anna. 2007. As lutas antirracistas de afrodescendentes sob vigilância do DEOPS/SP (1964-1983). 2007. Dissertação (Mestrado em História) - Programa de Pós-Graduação em História Social da Universidade de São Paulo, São Paulo, 2007.

LIMA, Lucas Pedretti. Bailes soul, ditadura e violência nos subúrbios cariocas na década de 1970. 2018. Dissertação (Mestrado em História) - Programa de PósGraduação em História da PUC-Rio, Rio de Janeiro, 2018.

MELLO, Zuza Homem de. A era dos festivais. São Paulo: Editora 34, 2003.

MAGALHÃES, Marionilde D. Brepohl de. A lógica da suspeição: sobre os aparelhos repressivos à época da ditadura militar no Brasil. Revista Brasileira de História, São Paulo, v. 17, n. 34, p. 203-220,1997.

MATTOS, Marcelo Badaró. O governo João Goulart: novos rumos da produção historiográfica. Revista Brasileira de História, São Paulo, v.28, n. 55, p. 245-263, 2008.

MARIA, Julio. Elis Regina: nada será como antes. São Paulo: Editora Master Books, 2015.

MACACOS NOS SEUS GALHOS: perigos, erros e excessos das imitações. Revista Veja, São Paulo, ed. 157, p. 79-82, 08 set. 1971.

OLIVEIRA, Luciana Xavier de. A cena musical da Black Rio: mediações e políticas de estilo nos bailes soul dos subúrbios cariocas dos anos 1970. 2016. Tese (Doutorado em Comunicação) - Programa de Pós-Graduação em Comunicação da Universidade Federal Fluminense, Niterói, 2016.

O POVO ELEGEU BR 3 E TONI TORNADO. Revista Aconteceu, Rio de Janeiro, 1970. Edição Especial V FIC. Capa.

O "SOUL" VEIO DE BR-3 ATÉ O RIO. Revista Aconteceu, Rio de Janeiro, 1970, p. 22-23. Edição Especial V FIC.

OS HERÓIS DA BR-3. Revista Amiga, Rio de Janeiro, n. 24, 3 nov. 1970. Capa.

O BRASIL TORCE PELA BR-R. Revista Manchete. Rio de Janeiro, 01 nov. 1970.

PARANHOS, Adalberto. A música popular e a dança dos sentidos: distintas faces do mesmo. ArtCultura: Revista do Instituto de História da Universidade Federal de Uberlândia, Uberlândia: EDUFU, n. 9, p. 22-31, jul./dez. de 2004. Dossiê História e Música 
PARANHOS, Adalberto. Sons de sins e de nãos: a linguagem musical e a produção de sentidos. Projeto História, São Paulo: Educ: FAPESP: Finep, n. 20, 2000.

PIRES, Thula R. de Oliveira. Estruturas intocadas: racismo e ditadura no Rio de Janeiro". In: Direito \& Práxis, Rio de Janeiro, v.9, n. 2, p. 1054-1079, 2018.

PAIVA, Carlos E. Amaral de. Black Pau: a soul music no Brasil nos anos 1970. 2015. Tese (Doutorado em Ciências Sociais) - Programa de Pós-Graduação em Ciências Sociais da UNESP, Araraquara, 2015.

POVO METRALHADO PELOS BANDIDOS DA SUBVERSÃO. Folha da Tarde, São Paulo, 01 abr. 1971.

QUANDO PUBLICIDADE DESVENDE. Folha de São Paulo, São Paulo, 11 out. 1971.

ROCHA, Décio; MENEZES, Leila Medeiros de. Uma abordagem discursiva da censura no Brasil em tempos de ditadura: Gonzaguinha e a resistência pela música. Revista Brasileira de História \& Ciências Sociais, Rio Grande, v. 6, n. 12, d p.73-90, dez. 2014

ROCHA, Décio; DEUSDARÁ, Bruno. Práticas de linguagem e produção de subjetividade: dimensões interdisciplinares dos discursos midiáticos”. In: Revista Intercâmbio, vol. XXIV, São Paulo, 2011, pp. 165-180.

SCOVILLE, Eduardo H. M. Lopes. 2008. Na barriga da baleia: a rede globo de televisão e a música popular brasileira na primeira metade da década de 1970. 2008. Tese (Doutorado em História) - Programa de Pós-Graduação em História, Universidade Federal do Paraná, Curitiba, 2008.

SALES JÚNIOR, Ronaldo Laurentino. Raça e justiça: o mito da democracia racial e o racismo institucional no fluxo de justiça. 2006. Tese (Doutorado em Sociologia) - Programa de Pós-Graduação em Sociologia da Universidade Federal de Pernambuco, Recife, 2006.

SANTOS, Gislene A dos. Selvagens, exóticos, demoníacos. ideias e imagens sobre uma gente de cor preta. Estudos Afro-Asiáticos, Rio de Janeiro, ano 24, n. 2, p. 275-289, 2002.

SCHWARCZ, Lilia. Nem preto nem branco, muito pelo contrário: cor e raça na intimidade. In: SCHWARCZ, Lilia Moritz (org.). História da vida privada no Brasil: contrastes da intimidade contemporânea. São Paulo: Companhia das Letras, 1998.

SEQUEIRA, Cleofe Monteiro de. A informação comprometida: o noticiário da Folha da Tarde durante a ditadura militar. ENCONTRO DOS NÚCLEOS DE PESQUISA DA INTERCOM, 4., 2004, Porto Alegre. Anais [...]. Porto Alegre, 2004. 
Disponível em: http://www.portalintercom.org.br/eventos1/congressonacional/2004. Acesso em: 08 jul. 2020.

SUED, Ibrahim. "A barato-3". Revista Veja, São Paulo, 11 nov. 1970, p. 24.

SOU negro. Intérprete: Toni Tornado. Compositores: Getúlio Côrtes e Ed Wilson. In: TONI Tornado. Intérprete: Toni Tornado. Odeon, 1970. 1 compacto simples, lado B, faixa 1 (2 min $18 \mathrm{seg})$.

TORNADO, Toni. Toni Tornado na BR-2006. [Entrevista cedida a] P. Alexandre Sanches. Carta Capital, São Paulo, ano 12, ed. 403, jul. 2006.

TONY TORNADO: FURACÃO NO FESTIVAL. Revista Intervalo, São Paulo, n. 407, 1970. Capa.

TONY TORNADO: A VIAGEM GLORIOSA PARA O SUCESSO. Revista Manchete, Rio de Janeiro, 01 nov. 1970. Capa.

TORNADO, Tony. [Entrevista cedida a] Amanda Palomo Alves, Rio de Janeiro (RJ), 20 ago. 2009.

TV TUDO - PAíS DO FESTIVAL. Revista Amiga, Rio de Janeiro, n. 26, p. 13, nov. 1970.

UM INSTANTE, MAESTRO! O Cruzeiro, Rio de Janeiro, p. 88, 01 dez. 1970.

VIANA, Larissa. Negros distintos nas Américas: escrita da história e protagonismo negro no pós-abolição. ENCONTRO INTERNACIONAL DA ANPHLAC, 11., 2014, Niterói. Anais [...]. Niterói, Rio de Janeiro, 29 jul. 2014 a 01 ago. 2014.

ZUMTHOR, Paul. A letra e a voz: a "literatura" medieval. São Paulo: Companhia das Letras, 2001.

Universidade do Estado de Santa Catarina - UDESC

Programa de Pós-Graduação em História - PPGH

Revista Tempo e Argumento

Volume 12 - Número 31 - Ano 2020 tempoeargumento@gmail.com 